No.1739

January 2021

\title{
Trade protection along supply chains
}

Chad Bown

Paola Conconi

Aksel Erbahar

Lorenzo Trimarchi 


\begin{abstract}
During the last decades, the United States has applied increasingly high trade protection against China. We combine detailed information on US antidumping (AD) duties - the most widely used trade barrier — with US input-output data to study the effects of trade protection along supply chains. To deal with endogeneity concerns, we propose a new instrument for $\mathrm{AD}$ protection, which combines exogenous variation in the political importance of industries with their historical experience in $\mathrm{AD}$ proceedings. We find that tariffs have large negative effects on downstream industries, decreasing employment, wages, sales, and investment. Our baseline estimates for 1988-2016 indicate that, due to AD protection against China, around 1.8 million US jobs were lost in downstream industries, with no significant job gains in protected sectors. When we extend the analysis to measures introduced under President Trump, we find that around 500,000 jobs were lost during the first two years of his term. We also provide evidence of the mechanisms behind the negative effects of protection along supply chains: $\mathrm{AD}$ duties decrease imports and raise production costs for downstream industries.
\end{abstract}

Key words: trade protection, supply chains, input-output linkages, employment. JEL codes: F13; D57

This paper was produced as part of the Centre's Trade Programme. The Centre for Economic Performance is financed by the Economic and Social Research Council.

Part of this paper builds on the earlier project circulated under the title "Trade Policy and the China Syndrome.” We are grateful to Pol Antràs, Tommaso Aquilante, Andy Bernard, Emily Blanchard, Davin Chor, Italo Colantone, Arnaud Costinot, Mathias Dewatripont, Ruben Durante, Sacha Kapoor, Josef Konings, Brian Kovak, Andrei Levchenko, Emanuel Ornelas, Justin Pierce, Vincent Rebeyrol, André Sapir, Peter Schott, Bob Staiger, Otto Swank, Denni Tommasi, Hylke Vandenbussche, Maurizio Zanardi, participants at the ETSG and CEBLF conferences, the FREIT SETC conference, the CESifo conference on the Global Economy, the Fifth Conference of CEPR Research Network on Global Value Chains, Trade and Development, the Workshop on International Economic Networks (WIEN), and seminar participants at Trinity College Dublin, ECARES, Lancaster University, Erasmus University Rotterdam, Syracuse University, Nottingham University, and the Empirical Trade Online Seminar (ETOS) for their helpful comments and suggestions, and Elisa Navarra for excellent research assistance. Paola Conconi gratefully acknowledges funding from the FNRS, the European Research Council (Advanced ERC Grant No. 834253) and the European Union's Horizon 2020 research and innovation programme (Agreement Grant No. 770680), while Lorenzo Trimarchi acknowledges funding from the FNRS (Excellence of Science Research No. O020918F).

Chad Bown, Peterson Institute and CEPR. Paola Conconi, Université Libre de Bruxelles, CEPR, CESifo, and Centre for Economic Performance, London School of Economics. Aksel Erbahar, Erasmus University. Lorenzo Trimarchi, Université de Namur.

Published by

Centre for Economic Performance

London School of Economics and Political Science

Houghton Street

London WC2A 2AE

All rights reserved. No part of this publication may be reproduced, stored in a retrieval system or transmitted in any form or by any means without the prior permission in writing of the publisher nor be issued to the public or circulated in any form other than that in which it is published.

Requests for permission to reproduce any article or part of the Working Paper should be sent to the editor at the above address.

(C) C. Bown, P. Conconi, A. Erbahar and L. Trimarchi, submitted 2021. 


\section{Introduction}

The last few decades have witnessed the rise of China as a world trading power. Thanks to China's deep economic reforms in the 1980s and 1990s and its membership in the World Trade Organization (WTO) since 2001, between 1990 and 2011, the share of global manufacturing exports originating from China surged from 2\% to 16\% (Acemoglu et al., 2016). To curb this rise in import competition, in 2018, the Trump administration introduced a series of tariff measures to limit trade with China, triggering retaliation. The trade war between the United States and China has stimulated several studies on the effects of this "return to protection" (e.g. Amiti et al., 2019; Flaaen and Pierce, 2019; Fajgelbaum et al., 2020; Flaaen et al., 2020). However, well before President Donald Trump took office, the US had already been targeting China through its most frequently used trade barrier antidumping (AD) duties. As shown in Figure 1, between the start of the presidency of George H. W. Bush in 1988 and the end of Barack Obama's second term in 2016, the average US AD duty against China more than tripled (from $45 \%$ to 148\%). Under President Trump, they further increased to $166 \%$.

\section{Figure 1}

Average AD duty against China (1988-2019)

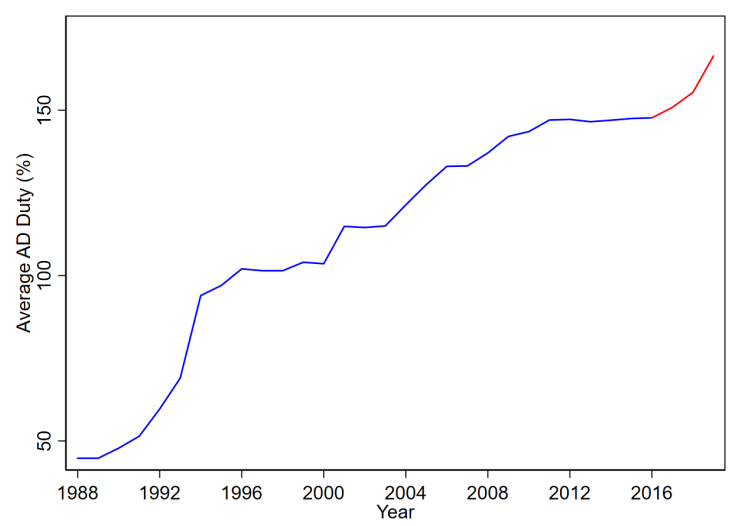

The figure plots the average AD duty applied by the United States on imports from China during 1988-2016 (in blue) and during Trump's presidency in 2017-2019 (in red). Source: Authors' calculations based on an extended version of the Temporary Trade Barriers Database of Bown (2014).

Over the same period, the share of Chinese imports covered by US AD duties has also dramatically increased (from $3.4 \%$ to $10.1 \%$ ), as shown in Figure A-1 in the Appendix. During Trump's presidency, this share reached $12.9 \%$.

The last decades have also witnessed the emergence of global supply chains and the rise of trade in intermediate goods (e.g. Yi, 2003; Johnson and Noguera, 2012; Antràs, 2020). 
In a world in which production processes are fragmented across countries, the effects of tariffs propagate along supply chains, with firms in downstream industries suffering from protection upstream. ${ }^{1}$ Such concerns are exacerbated by the fact that protection is often targeted towards intermediate inputs. ${ }^{2}$

In this paper, we examine the effects of trade protection along supply chains. We focus on $\mathrm{AD}$ duties, the most common trade barrier used by the United States and other WTO members (Blonigen and Prusa, 2016). ${ }^{3}$ In our main analysis, we study the effects of US AD duties applied against China during 1988-2016. China has been by far the biggest target of US AD protection: since its accession to the WTO, more than $70 \%$ of US AD measures have been against China. ${ }^{4}$ We collect detailed information on AD duties and other protectionist measures applied by the United States during the last decades and combine it with disaggregated US input-output data to identify vertical linkages between industries.

As pointed out by Trefler (1993), a key challenge to identify the effects of tariff changes is the endogeneity of trade policy. When studying the impact of tariffs along supply chains, a major concern is that the results might be confounded by omitted variables correlated with both the level of protection in upstream industries and the performance of downstream industries. For example, productivity shocks experienced by foreign input suppliers can benefit US firms in downstream sectors (e.g. allowing them to purchase inputs at lower prices) and also increase input protection (e.g. making it easier for an industry that petitions for AD to provide evidence of injury). Omitting these productivity shocks would thus work against finding negative effects of tariffs along supply chains. Other potential omitted variables, such as lobbying by downstream producers, can have similar effects. Higher tariffs on some inputs (e.g. steel or car parts) can hurt firms in vertically-related industries (e.g. construction companies, car manufacturers). These firms will then try to lobby against high tariffs on

\footnotetext{
${ }^{1}$ For example, it has been argued that Trump's tariffs "on bike components have raised the costs of Bicycle Corporation of America [BCA]" ... "tariffs on steel and aluminium have so disrupted markets that plans to expand BCA are on hold, costing American jobs" ("The Trouble with Putting Tariffs on Chinese Goods," The Economist, May 16, 2019).

${ }^{2}$ Bown (2018) shows that during the last few decades AD duties applied by the United States against China are increasingly skewed towards intermediate goods. He documents similar patterns when looking at measures applied by the United States against other countries, as well as measures applied by other advanced economies. In the recent trade war with China, US tariffs were also skewed towards intermediate inputs, such as primary metals and electrical equipment (Fajgelbaum et al., 2020).

${ }^{3}$ GATT/WTO rules allow three forms of temporary trade barriers (TTBs): AD duties to defend against imports sold at "less than fair value," countervailing duties to protect against subsidized imports, and safeguard tariffs in response to import surges. AD duties are the most common TTBs used by the United States against China during our sample period (see Figure A-2).

${ }^{4}$ During 2001-2016, China was the target of $73 \%$ of the new AD measures introduced by the United States; over the entire 1988-2016 period, $50 \%$ of the new measures were against China.
} 
their inputs, particularly if they stand to lose a lot from protection (e.g. Gawande et al., 2012; Mayda et al., 2018). If successful, these lobbying efforts would make it harder to identify the negative effects of protection along supply chains. ${ }^{5}$

Our paper makes two important contributions to the literature on the effects of trade protection. First, we propose a new instrumental variable for AD duties, the most widely used protectionist measure. Second, using this instrument, we identify the causal impact of trade barriers along supply chains. We show that tariffs have large negative effects on downstream industries, increasing production costs, and decreasing employment, wages, sales, and investment.

Our instrument is the interaction between an industry's historical experience at filing for AD petitions and its importance in political battleground states. The logic of our identification strategy is that AD protection should be skewed in favor of industries that are important in swing states, but only if they can exploit this political advantage thanks to their prior knowledge of the complex procedures to petition for $\mathrm{AD}$ duties.

The first component of the instrument builds on previous studies emphasizing the legal and institutional complexity of the AD process. The petitioning party must present substantial information to support the case, as well as legal analysis and arguments. As a result, industries with prior experience at filing $\mathrm{AD}$ cases face lower petitioning costs and a higher probability of success in new cases (Blonigen and Park, 2004; Blonigen, 2006). In line with these studies, we find that the number of petitions filed by an industry during our sample period is strongly correlated with its prior $\mathrm{AD}$ experience.

The second component builds on the literature on the political economy of trade policy. Several studies show that US trade policies are biased towards the interests of swing states (e.g. Muûls and Petropoulou, 2013; Conconi et al., 2017; Ma and McLaren, 2018; Fajgelbaum et al., 2020). ${ }^{6}$ Our paper provides novel evidence that swing-state politics shapes US $\mathrm{AD}$ duties. We show that congressmen from swing states are overrepresented in the two key committees that deal with trade policy in the US Congress. These committees can influence decisions of the International Trade Commission (ITC) - one of the two key institutions in charge of $\mathrm{AD}$ in the United States - through various channels (e.g. appointment confirma-

\footnotetext{
${ }^{5}$ For example, in 2006 "[t]he steel antidumping duties in the United States were brought down partly by a coalition of otherwise rival firms. The case against the steel duties brought together rival U.S. and Japanese auto makers - General Motors Corp., Ford, and Daimler-Chrysler AG joined forces with Toyota Motor Corp., Honda Motor Co., and Nissan Motor Co." (Wall Street Journal, December 16, 2006).

${ }^{6}$ These studies examine the effects of swing-state politics on non-tariff barriers under President Reagan (Muûls and Petropoulou, 2013), trade disputes initiated by the United States (Conconi et al., 2017), US MFN tariffs (Ma and McLaren, 2018), and Trump's 2018 tariffs (Fajgelbaum et al., 2020).
} 
tions, budget allocation, oversight hearings). ${ }^{7}$ One would then expect swing-state politics to affect ITC votes. Indeed, we find that ITC commissioners are more likely to vote in favor of AD when the petitioning industry is important in swing states.

We show that our instrument strongly predicts AD protection and is highly robust (e.g. to using different measures of AD protection, employing alternative definitions of swing states, extending the analysis to all TTBs and all targeted countries). To verify the logic behind our identification strategy, we carry out placebo tests, using randomized distributions of swing states. The results of these tests show that keeping track of changes in the identity of swing states across electoral terms is key to predicting AD protection.

Our analysis emphasizes the importance of dealing with the endogeneity of trade policy. If we ignore this concern, we find no systematic effect of tariffs along supply chains. When we instrument for trade policy, we find that higher tariffs have large negative effects on downstream industries, leading to a significant decline in the growth rate of employment, wages, sales, and investment.

In terms of magnitude, our baseline estimates indicate that a one percentage point increase in the average input tariff faced by a downstream industry leads to a 0.32 percentage point decrease in the annual growth rate of employment in that industry. Our estimates imply that during 1988-2016 more than 1.8 million US jobs were lost across all downstream industries due to $\mathrm{AD}$ protection against China, with no evidence of significant job gains in the protected industries. ${ }^{8}$ This figure corresponds to $4.8 \%$ of the 38 million jobs the US economy added during 1988-2016. The most negatively affected sectors were large nonmanufacturing industries (e.g. construction), which use inputs that were highly protected (e.g. steel). When we extend the analysis to protectionist measures introduced since Trump took office, we find that around 500,000 jobs were lost across all industries during the first two years of his presidency.

We show that our baseline results hold in a battery of robustness checks (e.g. using alternative AD measures, accounting for other protectionist measures, extending the analysis to all targeted countries, using different ways to capture input-output linkages, and different econometric methodologies).

We also provide evidence of the mechanisms behind the negative effects of tariffs along supply chains. We show that AD duties against China decrease US imports of targeted

\footnotetext{
${ }^{7}$ Previous studies (e.g. Moore, 1992; Hansen and Prusa, 1997; Aquilante, 2018) show that the composition of the Finance and Ways and Means committees affects the votes of ITC commissioners.

${ }^{8}$ Between 1988 and 2016, US employment declined in 70\% of the 4-digit Standard Industrial Classification (SIC4) industries. Our counterfactual estimates imply that, without AD protection, fewer jobs would have been destroyed in declining industries, and more jobs would have been created in expanding industries.
} 
products and raise production costs for downstream industries.

The rest of the paper is structured as follows. In Section 2, we briefly review the related literature. Section 3 provides information on the institutional procedures for the introduction of $\mathrm{AD}$ duties in the United States. Section 4 describes the data and variables used in our empirical analysis. Section 5 introduces our new instrument for AD protection. Section 6 presents our empirical results on the effects of protection along supply chains. Section 7 concludes, discussing the implications of our analysis for the ongoing debate about the use of protectionist measures in the multilateral trading system.

\section{Related Literature}

Our paper is related to three main streams of literature. First, it contributes to the literature on trade policy and global sourcing. Various studies have emphasized the productivityenhancing effects of input trade and input liberalization (e.g. Amiti and Konings, 2007; Goldberg et al., 2010; Halpern et al., 2015; Antràs et al., 2017; Blaum et al., 2018). Others have examined the effects of trade policy along value chains (e.g. Yi, 2003; Blanchard et al., 2016; Erbahar and Zi, 2017; Conconi et al., 2018; Vandenbussche and Viegelahn, 2018; Barattieri and Cacciatore, 2020; Bown et al., 2020; Grossman and Helpman, 2020). We contribute to this literature by exploiting a rich dataset covering all trade barriers introduced by the United States since the 1980s and employing an instrumental variable approach to address concerns about the endogeneity of trade policy.

Second, our analysis is related to the literature on AD protection (see Blonigen and Prusa (2016) for comprehensive review). Some studies have examined the direct effects of AD duties on imports from targeted countries. ${ }^{9}$ Other studies have considered the indirect effects on third countries. ${ }^{10}$ To deal with the endogeneity of AD protection, some authors have combined a difference-in-differences methodology with propensity score matching (Konings

\footnotetext{
${ }^{9}$ For example, Prusa (2001) provides evidence for the trade destruction effect of AD protection, showing that US AD measures decreased imports of targeted products by between $30 \%$ and $50 \%$. On the extensive margin, Besedes and Prusa (2017) find that US AD increases the probability of foreign firms exiting the US market by more than $50 \%$. Lu et al. (2013) use detailed transaction data on Chinese firms and find that an increase in US AD duties leads to a significant drop in Chinese exports to the United States.

${ }^{10}$ Prusa (1997) and Konings et al. (2001) focus on trade diversion, showing that AD duties targeting one country can lead to an increase in imports from non-targeted countries. Bown and Crowley (2007) show that $\mathrm{AD}$ measures can give rise to trade deflection (i.e. an increase in exports from targeted countries to third countries) and trade depression (i.e. a decrease in exports from the targeted country to third countries). Antidumping can also have negative effects on aggregate trade, deterring imports from foreign firms that are not actually targeted. Vandenbussche and Zanardi (2010) estimate that these "chilling effects" account for about a $6 \%$ decrease in aggregate imports.
} 
and Vandenbussche, 2008; Pierce, 2011). Ours is the first paper to propose an instrumental variable for $\mathrm{AD}$ duties. As mentioned before, our instrument builds on the literature on the determinants of AD protection (e.g. Finger et al., 1982; Bown and Crowley, 2013), and in particular on those studies that emphasize the role of $\mathrm{AD}$ experience (e.g. Blonigen and Park, 2004; Blonigen, 2006) and domestic political factors (e.g. Moore, 1992; Hansen and Prusa, 1997; Aquilante, 2018).

Finally, our paper is related to the literature on US-China trade relations. Several influential studies have examined the effects of import competition from China on US employment (e.g. Autor et al., 2013; Acemoglu et al., 2016; Pierce and Schott, 2016). ${ }^{11}$ We study instead the effects of US trade protection against China. A recent stream of the literature studies the effects of the US-China trade war. Amiti et al. (2019) examine the impact on prices and welfare. They show that tariff changes had little-to-no impact on the prices received by foreign exporters, indicating that the incidence of Trump's tariffs has fallen entirely on domestic consumers and importers. ${ }^{12}$ Flaaen and Pierce (2019) find that the tariffs introduced by the Trump administration in 2018-2019 drove up the cost of inputs for American manufacturers and, combined with retaliation by trading partners, destroyed manufacturing jobs. Similarly, Flaaen et al. (2020) find significant price effects due to US import restrictions on washing machines. Our analysis differs from recent studies of the US-China trade war along two main dimensions. First, rather than restricting the analysis to the Trump era, we study the effects of protection over several decades, exploiting variation in AD duties against China over time and across products. Second, we employ an instrumental variable approach to deal with the endogeneity of trade policy.

\section{Antidumping in the United States}

Antidumping measures are meant to protect domestic producers against unfair trade practices by foreign firms. Under Article VI of the General Agreement on Tariffs and Trade (GATT) and US trade laws, dumping occurs when goods are exported at a price "less than fair value" (LTFV), i.e. for less than they are sold in the domestic market or at less than production cost. Multilateral trade rules allow unilateral measures against dumped imports causing material injury to domestic producers.

\footnotetext{
${ }^{11}$ Other studies have considered the effects of the "China Syndrome" on other outcomes, such as marriage and fertility patterns (Autor et al., 2019), innovation (Autor et al., 2020b), the polarization of US politics (Autor et al., 2020a), and mortality (Pierce and Schott, 2020).

${ }^{12}$ This complete pass-through result is also supported by other studies (e.g. Cavallo et al., 2019; Fajgelbaum et al., 2020).
} 
In the United States, AD is administrated by two agencies, each with different competences: the US Department of Commerce (DOC), ${ }^{13}$ which is in charge of the dumping investigation, and the US International Trade Commission (ITC), which is in charge of the injury investigation. The DOC is an integral part of the US Administration, while the ITC is a bipartisan agency composed of six commissioners nominated by the President and confirmed by the Senate (with no more than three commissioners from the same political party).

An AD case starts with a petition filed to the ITC and the DOC, claiming injury caused by unfairly priced products imported from a specific country. ${ }^{14}$ US manufacturers or wholesalers, trade unions, and trade or business associations are all entitled to be petitioners, to the extent that they represent their industries. The petitioning process is extremely complex and requires petitioners to provide extremely detailed information about the case. ${ }^{15}$

Once a petition has been filed, the DOC decides whether a product is "dumped", i.e. imported at LTFV. The calculation of the dumping margin involves a complex procedure. According to the law, the DOC defines fair value as the foreign firm's price of the same good in its home country. However, this price is not always available, either because the foreign firm's sales in its home market are negligible or because the home country is a nonmarket economy. If this is the case, the DOC can base the calculation of the fair value on the exporting firm's price in third countries or on a constructed value based on the foreign firm's costs, when this information is provided. ${ }^{16}$ A product is declared to be dumped if the dumping margin is above a threshold established by the DOC.

\footnotetext{
${ }^{13}$ Before 1980, the US Department of Treasury was in charge of dumping investigations. The US Congress decided to move this responsibility from the Treasury to the Department of Commerce, which was seen as more inclined to protect US firms and workers than the Treasury (Irwin, 2005).

${ }^{14} \mathrm{An} \mathrm{AD}$ case may concern multiple AD petitions involving different countries exporting the same product. For instance, in 2008, the AD case (USITC investigations 731-TA-1118 - 731-TA-1121) regarding "LightWalled Rectangular Pipe and Tube" targeted imports from China, Korea, Mexico, and Turkey.

${ }^{15}$ Among others, petitioners must provide: the identity of all producers in the industry and their position regarding the petition; detailed description of the imported merchandise, including technical characteristics and uses; the volume and value of each firm's exports of the merchandise to the United States during the last 12 months; the home market price in the country of exportation (or the price from the country of exportation to a third country); evidence that sales in the home market are being made at a price which does not reflect the cost of production and the circumstances under which such sales are made; the petitioner's capacity, production, domestic sales, export sales, and end-of-period inventories of U.S.-produced merchandise like or most similar to the allegedly dumped imports in the three most recent calendar years and in the most recent partial-year periods for which data are available; detail description and supporting documentation of the material injury to the industry due to the increased level of imports (e.g. lost sales, decreased capacity utilization, or company closures) (see Guidelines for Antidumping Duty Petitions).

${ }^{16}$ Article 15 of China's Protocol of Accession to the WTO allowed other WTO members to treat China as a non-market economy (NME) until December 2016. To this day, the United States has refused to grant the status of a market economy to China. Given its NME status, the DOC relies on third surrogate countries to determine the dumping margin. This results in the imposition of larger duties on Chinese products.
} 
In the administration of antidumping, the ITC is in charge of the injury investigation. Under Section 201 of the Trade Act of 1974, the ITC "determines whether an article is being imported into the United States in such increased quantities as to be a substantial cause of serious injury, or the threat thereof, to the domestic industry producing an article like or directly competitive with the imported article." If the ITC finds that the relevant US industry has been materially injured, or threatened with material injury, as a result of the unfairly traded imports, an AD duty equal to the dumping margin established by the DOC is introduced.

During 1981-2018, the DOC ruled in favor of dumping in $81 \%$ of the cases, with significant variation in the proposed duty rates (the mean and maximum rates are respectively $65 \%$ and $493 \%$, and the standard deviation is $79 \%$ ). During the same period, the ITC ruled in favor of injury in $68 \%$ of the cases. ${ }^{17}$ Note also that AD measures are supposed to be temporary and can only be extended after the initial five-year period through an expiry review. However, Bown et al. (2020) show that US AD duties lasted on average for 12 years, with some measures imposed in the 1980s still in effect as of 2020 .

\section{Data and Variables}

In this section, we describe the data used in our empirical analysis and the variables we construct to study the effects of trade protection along supply chains.

\subsection{Data on Input-Output Linkages}

The first source of data used in our empirical analysis is the US input-output tables from the US Bureau of Economic Analysis (BEA), which we use to identify vertical linkages between industries. Following Acemoglu et al. (2016), we employ the 1992 Use of Commodities by Industries After Redefinitions (Producers' Prices) tables. We use their concordance guide to convert 6-digit BEA industry codes into 4-digit Standard Industry Classification (SIC4) codes to be able to combine input-output tables with industry-level data. This allows us to identify linkages between 479 industries, including both manufacturing and non-manufacturing (e.g. construction, services). The disaggregated nature of the US input-output tables is one of the reasons why they have been used to capture technological linkages between sectors even in cross-country studies (e.g. Acemoglu et al., 2009; Alfaro et al., 2016 and 2019).

\footnotetext{
${ }^{17}$ These statistics concern the final dumping and injury investigations. The DOC and the ITC also conduct preliminary investigations (see Antidumping and Countervailing Duty Handbook for more details).
} 
For every pair of industries, $i j$, the input-output accounts provide the dollar value of $i$ required to produce a dollar's worth of $j$. We denote with $\omega_{i, j}$ the direct requirement coefficient for the sector pair $i j$, i.e. the dollar value of $i$ used as an input in the production of one dollar of $j$. In our baseline regressions, we use this variable to capture direct vertical linkages between industries. In robustness checks, we use total requirements coefficients, denoted with $\theta_{i, j}$, which take into account indirect linkages. ${ }^{18}$

Panels (a) and (b) of Figure A-3 in the Appendix illustrate the average $\omega_{i, j}$ across all SIC4 $j$ industries, focusing respectively on the top-10 and top-50 most important inputs (i.e. with the highest $\omega_{i, j}$ ). Notice that the distribution of input-output linkages is highly skewed, with the most important input accounting for a much larger cost share.

\subsection{Data on Tariffs}

\section{Antidumping Duties and Other Temporary Trade Barriers}

Our main source for the tariff data is the World Bank's Temporary Trade Barriers Database (TTBD) of Bown (2014), which we have updated to include all measures introduced by the United States to the present.

The TTBD contains detailed information on three forms of contingent protection (antidumping duties, countervailing duties, and safeguards) for more than thirty countries since 1980. For each case, it provides the identity of the country initiating it, the identity of the country subject to the investigation, the date of initiation of the investigation, the date of imposition of the measure (if the case is approved), as well as detailed information on the products under investigation. For the US, product data are extremely detailed with petitions identified at the 10-digit Harmonized Tariff Schedule (HTS) level (or at the 5-digit Tariff Schedule of the United States Annotated for years before 1989). Thanks to this granularity, it is possible to link each investigation with the corresponding 4-digit SIC code.

We first harmonize HS codes over time to the HS 1992 nomenclature, using the concordance tables provided by the United Nations Statistics Division. Then, we match the HS to the SIC classification using the following procedure: ${ }^{19}$

1. Each 10-digit HTS code is first aggregated up to the universal 6-digit Harmonized System (HS6) level. Then, each HS6 code is matched with one or more 4-digit SIC code

\footnotetext{
${ }^{18}$ Total requirements coefficients show the sum of direct and indirect purchases required to produce a dollar of output. Indirect purchases necessary to produce a car, for example, include the aluminum used in the frame and engine, as well as the electricity necessary to produce the aluminum.

${ }^{19}$ Throughout, when we refer to SIC industries, we use the "sic87dd" scheme used by Autor et al. (2013). These codes are slightly coarser than the 1987 SIC codes.
} 
using the crosswalk provided by Autor et al. (2013). Around $99 \%$ of the observations are mapped using this correspondence table. ${ }^{20}$ In order to map each HS6 product to only one industry, we assign an HS6 code to the industry which accounts for the largest share of that product's US imports. This means that each HS6 product is mapped to only one 4-digit SIC industry. However, each AD case may involve multiple HS6 products and thus be linked to more than one SIC4 code.

2. The remaining unmatched HS6 products are mapped to a SIC code by aggregating up the information in the crosswalk to the HS4 level. In this case, a product is matched to an industry if its correspondent HS4 family maps to only one SIC4 industry. All the unmatched HS6 products are manually matched to a corresponding SIC4 industry by directly retrieving information about the corresponding AD case from the ITC case descriptions.

In our empirical analysis, we focus on $\mathrm{AD}$ duties introduced by the United States against China. As mentioned before (see footnote 4), China was the most frequent target of US AD protection in our sample period. During the seven presidential terms covering 1988-2016, the US initiated 185 cases in which China was accused of dumping. In $74 \%$ of those cases, the US imposed measures on Chinese products. In robustness checks, we consider other protectionist measures and other countries targeted by the United States.

Our main measure of AD protection is Tariff $_{i, t}$, which is the average AD duty on imports from China in SIC4 industry $i$ in year $t .^{21}$ Table A-2 panel (a) reports descriptive statistics of this variable during 1988-2016. The average level of the AD duty is 15\%, with a standard deviation of $53 \%$ and a maximum of $430 \%$. Table A-5 lists the 10 sectors that have the highest average AD duty in 1988-2016. To deal with outliers, in the empirical analysis, we winsorize the Tariff $_{i, t}$ variable at the $5^{\text {th }}$ and $95^{\text {th }}$ percentiles.

The variable Tariff $_{i, t}$ captures mostly variation in the intensive margin of AD protection. In robustness checks, we use the following alternative measures, which better capture variation in the extensive margin of AD protection: Product Coverage $i_{i, t}$ is the share of HS6 goods

\footnotetext{
${ }^{20}$ For the years up to 1988 , descriptions of products were provided according to the Tariff Schedule of the United States Annotated (TSUSA) classification. Therefore, for AD cases before 1988, we match each TSUSA code with a corresponding HS code using the correspondence table provided by Feenstra (1996), available at http://cid.econ.ucdavis.edu/usix.html.

${ }^{21}$ To construct this measure, we average across all duties in force against China in industry $i$ in year $t$. Note that the level of the AD duty might differ across targeted firms within an AD investigation. We use the "all others" AD rate which is applied to all firms that are not specifically named in the investigation, and is usually higher than the ones applied to specific firms. Our results continue to hold if we use the average $\mathrm{AD}$ rate across firms. This is not surprising given the high correlation between the two rates (0.85).
} 
in sector $i$ covered by AD duties against China in year $t$; and Import Coverage $e_{i, t}$ is the share of imports in sector $i$ covered by AD duties against China in year $t .{ }^{22}$

Since the start of Trump's presidency in January 2017 and until 2019, the United States has continued to target imports from China, initiating 31 new AD cases, and imposing 32 measures. ${ }^{23}$ Figure 1 shows this recent increase in average AD duties against China, as highlighted by the red solid line. When extending our analysis to the measures introduced under President Trump, we cover the first two years of his term, since the industry-level employment data is only available until the end of 2018. Table A-2 panel (c) reports descriptive statistics on AD duties during 2017-2018, which reveal that AD protection has further increased under Trump with the average AD duty reaching $36 \%$, with a standard deviation of $81 \%$.

Combining data on input-output linkages from the BEA with data on tariffs, we can construct different variables capturing the degree of input protection faced by downstream industries. Our main measure captures the average level of input protection:

$$
\text { Average Input Tariff }{ }_{j, t}=\sum_{i=1}^{N} \omega_{i, j} \text { Tariff }_{i, t} \text {, }
$$

where $\omega_{i, j}$ is the cost share of input $i$ in the production of SIC4 good $j$, and Tariff $f_{i, t}$ is the AD duty applied on Chinese imports in industry $i$ in year $t$. Thus, $\sum_{i=1}^{N} \omega_{i, j}$ Tariff $_{i, t}$ is the average $\mathrm{AD}$ duty on inputs faced by downstream industry $j$. Notice that the set $N$ includes all 405 tradable sectors in the economy, to which import tariffs can apply. ${ }^{24}$

As mentioned in Section 4.1, the distribution of vertical linkages is highly skewed (see Figure A-3). For example, when looking at tradable inputs, steel (SIC 3312) is the most important input for $17 \%$ of the industries (see Table A-6). Our second measure of input tariff captures the level of protection on key inputs:

$$
\text { Tariff on Key } \text { Input }_{j, t}=\text { Tariff }_{1, i, t} \text {, }
$$

where $\operatorname{Tariff}_{1, i, t}$ is the AD duty applied in year $t$ on Chinese imports of sector $j$ 's most important input (with highest $\omega_{i, j}$ ).

As mentioned before, in line with Acemoglu et al. (2016), we rely on the BEA's 1992

\footnotetext{
${ }^{22}$ This variable is constructed using import data of the year prior to the filing of the AD petition. We use lagged import values to deal with the endogeneity of contemporaneous import values to trade protection.

${ }^{23}$ Of the new measures, nine were due to investigations that started before Trump took office.

${ }^{24}$ These include all manufacturing industries, agriculture, and mining.
} 
input-output tables to identify vertically-related industries. If technology changes over time, this can lead to measurement error in input protection. Notice, however, that concerns about measurement only apply to the average input tariff (1), since our alternative measure (2) relies on IO coefficients solely to identify the key input, which is unlikely to change over time. Moreover, data from the BEA's 1997-2018 aggregate IO tables show little variation in the $\omega_{i, j}$ weights. This can be seen in Figure A-4, which plots the direct requirement coefficients for 1997 and 2018. The correlation between them is 0.93 .

Table A-2 panel(a) reports descriptive statistics of our two main measures of input tariffs. The average input tariff in 1988-2016 was $14 \%$ (with a standard deviation of 15\%), while the average tariff on the key input was 36\% (with a standard deviation of $63 \%$ ). Table A-7 lists the ten SIC4 industries with the highest level of input protection. These include a variety of manufacturing industries such as SIC 3449 ("Miscellaneous metal work"), 2821 ("Plastics materials and resins") and 3465 ("Automotive stampings"). Among the key inputs subject to high AD duties are SIC 3312 ("Blast furnaces and steel mills") and 2621 ("Paper mills") for which the average AD duty against China during 1988-2016 was respectively $82 \%$ and $77 \%$.

\section{MFN Tariffs}

Even though this paper's focus is on antidumping, we have also collected data on the US' most-favored-nation (MFN) tariffs that are applied to imports from other GATT/WTO members. The source for MFN tariffs is the World Integrated Trade Solution (WITS) database.

MFN tariffs emerge from long rounds of multilateral trade negotiations: at the end of each round, governments commit not to exceed certain tariff rates, and tariff bindings can only be altered in a new round of negotiations. Unlike AD duties, they must be applied in a non-discriminatory manner to imports from all countries (Article I of the GATT).

Table A-2 panel (b) reports descriptive statistics of the MFN tariffs applied by the United States since the beginning of our sample period. Comparing these with the corresponding statistics in Table A-2 panel (a), notice that MFN tariffs are on average much lower than the $\mathrm{AD}$ duties applied against China and vary little over time. ${ }^{25}$

\footnotetext{
${ }^{25}$ For the 1988-2016 period, the mean applied MFN tariff is 5\% (instead of 15\% for AD duties), though there is considerable cross-product variation (the standard deviation is $21 \%$ and the maximum rate is $350 \%$ ). Within SIC4 industries, there is little variation in US MFN tariffs over time: during most of our sample period, the rates applied by the United States coincide with the tariff bindings agreed at the end of the Uruguay Round of multilateral trade negotiations (1986-1994). For this reason, in our benchmark results, we abstract from MFN tariffs, which we include in robustness checks.
} 


\section{Additional Tariffs Under President Trump}

In 2018, the Trump administration introduced tariffs on hundreds of goods under three rarely used US trade laws (Sections 201 and 301 of the Trade Act of 1974, Section 232 of the Trade Expansion Act of 1962). ${ }^{26}$ These were stacked on top of AD duties already applying to Chinese imports. Some of Trump's tariffs have hit China exclusively, while others have hit China along with other countries. We have collected information on these additional tariffs, which covered $\$ 303.7$ billion, or $12.6 \%$ of US imports in 2017 (Bown, 2019).

Relative to AD duties, the special tariffs introduced by Trump vary much less across SIC4 industries. This can be seen by comparing the statistics reported in panels (c) and (d) of Table A-2: the average special tariff against China in 2018 was $11 \%$ (with a standard deviation of 7\%), while the average AD duty against China in 2017-2018 was 36\% (with a standard deviation of $81 \%$ ).

\subsection{Other Data}

In our empirical analysis, we make use of four other datasets:

- US Census County Business Patterns (CBP): we use this dataset to study the effects of input protection on employment. The CBP provides information on industry-level employment up to 2018. The variable Employment $t_{i, t}$ measures total employment in SIC4 industry $i$ in year $t$.

- United Nations (UN) Comtrade database: we use this dataset to measure imports. Comtrade provides information on bilateral trade flows at the HS6 level. The variable Imports $_{i, t}$ is the value of imports (expressed in real 2007 dollars). To map trade flows in HS to a SIC4 industry, we use the crosswalk provided by Autor et al. (2013). When an HS6 product is matched to multiple SIC4 industries, the associated value of imports is included in the imports of the matched industry weighted by the product's share of US imports in that specific SIC industry.

\footnotetext{
${ }^{26}$ On February 7, the United States introduced safeguard measures on solar panels and washing machines (at duty rates of 30\% and 20\%, respectively) under Section 201 of the Trade Act of 1974, which permits the President to grant temporary import relief, by raising tariffs on goods entering the United States that injure or threaten to injure domestic industries. On March 23, it implemented 25\% tariffs on steel and $10 \%$ tariffs on aluminum under Section 232 of the Trade Expansion Act of 1962, which gives the President authority to restrict imports in the interest of national security. On July 6, August 23, and September 24, the US implemented tariffs of $25 \%, 25 \%$, and $10 \%$, respectively, on different sets of products from China under Section 301 of the Trade Act of 1974, which gives the President authority to impose tariffs against countries that make unjustified, unreasonable, or discriminatory trade actions.
} 
- US Bureau of Labor Statistics (BLS): we use this dataset to measure domestic prices. The variable Domestic Price $_{i, t}$ is the producer price index (PPI) in SIC4 industry $i$ in year $t .^{27}$

- NBER-CES Manufacturing Industry Database: we use this dataset to study the effects of tariffs on various industry outcomes. The CES database allows us to construct the variables Blue Collar Workers $_{i, t}$ and White Collar Workers W $_{i, t}$ (number of blue-collar and white-collar jobs, in thousands), as well as real Wages $_{i, t}$ (in dollars), Sales $i, t$ and Investment $_{i, t}$ (in millions of dollars). Using the NBER-CES database, we also construct the variable Input Price $_{i, t}$ by dividing the nominal cost of materials by the real cost of materials.

To deal with outliers, in our analysis of the effects of protection along supply chains, we winsorize all outcome variables (e.g. the growth rate of employment, wages, sales, investment, imports, and prices) at the $5^{\text {th }}$ and $95^{\text {th }}$ percentiles.

\section{$5 \quad$ Identification Strategy}

\subsection{Endogeneity Concerns}

The goal of our paper is to study the effects of protection along value chains, using detailed information on input-output linkages and exploiting variation in US tariffs across industries and over time. As pointed out by Trefler (1993), the endogeneity of trade policy poses a major challenge to examining the effects of tariff changes. In particular, when studying the impact of tariffs along supply chains, a major concern is that the results might be confounded by unobservables that are correlated both with the level of protection in upstream industries and the performance of downstream industries

One example is productivity shocks, which can be positively correlated with both the growth of downstream industries and the degree of input protection. For instance, a positive productivity shock experienced by foreign input suppliers, which allows them to lower their prices, should benefit US firms in downstream sectors. The sane shock can also lead to an increase in input protection: in the case of AD investigations, a surge in the volume of imports makes it more likely that the industry petitioning for protection passes the injury test, which largely determines whether the duties are implemented. Omitting foreign input

\footnotetext{
${ }^{27}$ We normalize both import and domestic prices of each industry to 100 for the year 2000 to create a harmonized price index.
} 
productivity shocks would thus work against finding negative effects of tariffs along supply chains.

Similar concerns are raised by other potential omitted variables, including lobbying. Higher tariffs in upstream industries can increase production costs for downstream industries. Final good producers (e.g. construction companies, car manufacturers) will thus lobby against high tariffs on their inputs (e.g. steel, car parts), particularly if they stand to lose a lot from input protection. ${ }^{28}$ If downstream firms successfully lobby against input protection, simple ordinary least squares (OLS) coefficients will be biased upwards, making it harder to identify the negative effects of protection along supply chains.

\subsection{A New Instrument for Trade Protection}

To deal with these endogeneity concerns, we follow an instrumental variable (IV) approach. The logic of our identification strategy is that the level of AD protection granted to an industry should depend on its ability to petition for AD protection and on politicians' incentives to favor key industries in swing states. Our instrument is defined as follows:

$$
I V_{i, T}=\text { Experience }_{i} \times \text { Swing }_{i, T} .
$$

The first component of the instrument, Experience ${ }_{i}$, captures exogeneous variation in the ability of different industries to petition for $\mathrm{AD}$ protection. It exploits the fact that, due to the legal and institutional complexity of the AD process, industries with prior experience in $\mathrm{AD}$ cases face lower costs of filing and a higher probability of success in new cases (Blonigen

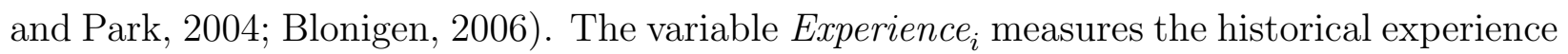
of industry $i$ at filing petitions for AD duties. In Section 5.2.1, we provide more details about the construction of this variable and show that it is strongly correlated with the number of petitions filed by an industry during our sample period.

The second component of the instrument, $\operatorname{Swing}_{i, T}$, captures exogenous variation in the political importance of industries driven by swing-state politics. It builds on the idea that politicians have incentives to use trade policy to favor important industries in swing states (e.g. Muûls and Petropoulou, 2013; Conconi et al., 2017; Ma and McLaren, 2018; Fajgelbaum et al., 2020). The variable Swing $_{i, T}$ measures the importance of industry $i$ in states classified as swing during presidential term $T$. In Section 5.2.2, we describe the construction of this

\footnotetext{
${ }^{28}$ The literature on political economy of trade policy shows that this type of lobbying is at work (e.g. Gawande et al., 2012; Mayda et al., 2018).
} 
variable, which exploits changes in the identity of swing states across presidential terms and differences in the (pre-sample) importance of industries across states. We also provide evidence that swing state politics affects decisions of AD authorities: ITC commissioners are more likely to vote in favor of a petitioning industry when this industry is more important is swing states.

As discussed in Section 5.3, combining the two components of the instrument is key to predicting AD protection: by themselves, Experience ${ }_{i}$ and Swing $_{i, T}$ cannot explain the observed variation (within and across industries) in AD duties. ${ }^{29}$

\subsubsection{Experience $_{i}$}

As explained in Section 3, AD investigations in the United States begin with a petition by a domestic party, usually a group of producers competing with the imported product that is allegedly dumped. The DOC and the ITC then conduct investigations to determine whether there is indeed dumping and whether this "unfair trade" practice is injuring the domestic industry represented by the petitioners. If these criteria are satisfied, an AD duty equal to the dumping margin calculated by the DOC is applied to the imported product.

As pointed out by Blonigen (2006), the process to petition for AD duties is extremely complex (see also footnote 15): "the petitioning party must present the AD authorities with a reasonable petition that presents their case for the investigation and then provide substantial information, as well as legal analysis and arguments, during the course of the investigation. The legal details, as well as the practical issues of how government agencies apply the law, are substantial" (p. 716). As a result of this complexity, prior experience by petitioning parties plays an important role in AD filings and outcomes. Blonigen shows that previous experience lowers future filing costs and increases petitioners' effectiveness in arguing their case, generating higher probabilities of favorable outcomes.

Following this idea, we use information on AD petitions filed by US industries during

\footnotetext{
${ }^{29}$ Combining the two components also allows us to address concerns about the exclusion restriction. To obtain a consistent estimate of the causal impact of antidumping, our proposed instrumental variable should be uncorrelated with any other determinant of the dependent variable (Angrist and Pischke, 2009). If we were to rely only on the variable Swing $_{i, T}$ when studying the effects of trade protection on employment and other industry outcomes, one may be concerned that this variable could be picking up the effects of other federal policies (e.g. subsidies) aimed at favoring important industries in swing states. Given that our instrument is the interaction between Experience ${ }_{i}$ and Swing $_{i, T}$, it only exploits variation in the political importance of an industry to the extent that this is relevant for $\mathrm{AD}$ protection: our instrument predicts no AD protection for industries that are important in swing states (high $S_{\text {wing }}{ }_{i, T}$ ) but cannot exploit this political advantage due to their lack of $\mathrm{AD}$ experience $\left(\right.$ Experience $\left._{i}=0\right)$. This allows us to isolate the effects of the political importance of an industry on $\mathrm{AD}$ protection from the effects of other policies that may be used to favor key industries in swing states.
} 
our pre-sample period to construct a measure of an industry's ability to obtain protection. During the 1980s, legal and institutional changes in AD proceedings made it easier to file for $\mathrm{AD}$ protection, which led to a steep increase in the number of $\mathrm{AD}$ petitions (see Irwin 2005 and 2017). Our experience variable is the count of AD petitions filed by industry $i$ in 1980-1987:

$$
\text { Experience }_{i}=\sum_{t=1980}^{1987} A D \text { Petitions }_{i, t} .
$$

This variable is meant to capture exogenous variation in industries' ability to petition for $\mathrm{AD}$ protection, coming from their historical (pre-sample) knowledge of AD procedures. To ensure exogeneity of the instrument, we exclude petitions targeting China and leading to measures in force after 1987.

The variable Experience Ex $_{i}$ is positive for $40 \%$ of all tradable industries. There is significant cross-sectoral variation in the number of AD cases initiated during this period (the variable Experience $_{i}$ has a mean of 0.73 and a standard deviation of 2.83), possibly due to the fact that some industries did not need to file for $\mathrm{AD}$, since they were already protected by other policies (e.g. voluntary export restraints, Multi-Fibre Arrangement). ${ }^{30}$ Descriptive statistics of the variable Experience $_{i, t}$ are reported in Table A-3. The top panel of Table A-4 lists the top-10 SIC4 sectors with the highest value of Experience ${ }_{i}$ during 1980-1987. ${ }^{31}$

In line with Blonigen (2006), we find that the number of petitions filed by an industry depends crucially on its previous experience: the correlation between the number of petitions filed by SIC4 industry $i$ in 1980-1987 and Experience $_{i}$ is 0.86.

\subsubsection{Swing $_{i, T}$}

The second component of our instrument exploits variation in the supply side of AD protection driven by swing-state politics in the United States. In US presidential elections, voters do not directly choose the executive, they vote for their state's representatives in the Electoral College, who then vote for the president. The winner-take-all nature of the Electoral

\footnotetext{
${ }^{30}$ One could be concerned that the cross-sectoral variation in the experience variable may be driven by differences in industry concentration: firms in more concentrated industries may find it easier to cooperate when filing AD petitions. If this is the case, higher Experience ${ }_{i}$ may capture the ability of more concentrated industries to coordinate (e.g. Olson, 1965; Bergstrom et al., 1986; Bombardini and Trebbi, 2012), rather than their knowledge of $\mathrm{AD}$ procedures. We have verified that this is not the case: the Herfindahl index of sales concentration and the Ellison-Gleaser index of geographical concentration have low and insignificant correlations with Experience E $_{i}(-0.003$ and 0.025, respectively).

${ }^{31}$ The highest number of petitions (57) was filed by the steel industry (SIC 3312). In robustness checks, we verify that our results are robust to winsorizing the experience variable and excluding steel from our sample.
} 
College implies that candidates can count some states as "safe," comfortably in the hands of their party. The states that really matter are the "swing" or "battleground" states, in which a few thousand or even a few hundred votes can shift the entire pot of electors from one candidate to the other.

Several studies show that US trade policies are biased towards the interests of swing states. $^{32}$ Muûls and Petropoulou (2013) show that states classified as swing in President Reagan's first term benefited from higher protection. Conconi et al. (2017) find that trade disputes initiated by the United States are more likely to involve important industries in swing states. Ma and McLaren (2018) show that swing-state politics affects US MFN tariffs. Fajgelbaum et al. (2020) find that the tariffs introduced by Trump in 2018 were targeted toward sectors concentrated in politically competitive counties. In this paper, we show that swing-state politics can also shape AD duties, the protectionist measure most widely used by the United States.

To define swing states, we use information on the difference in vote shares of Democratic and Republican candidates in the previous presidential election, in line with the literature. In particular, the dummy variable Swing $_{s, T}$ classifies a state $s$ to be swing during a presidential term $T$ if the difference in the vote shares of the candidates of the two main parties in the previous presidential election was less than 5\%. In robustness checks, we use alternative definitions of swing states.

Figure 2 illustrates the states classified as swing during the last eight presidential terms, based on the difference in vote shares in the previous presidential elections. Notice that both the number and identity of swing states vary significantly across terms. ${ }^{33}$

\footnotetext{
${ }^{32}$ The argument that US politicians use trade policy to favor the interests of swing states is also often heard in the media. For example, an article in the Guardian pointed out that in a letter to Pascal Lamy (Europe's former top trade negotiator), Stephen Byers (former UK secretary of state for trade and industry) wrote that the 2002 US steel tariffs were introduced by President George W. Bush "to gain votes in key states like West Virginia, Ohio, Pennsylvania and Michigan where the steel industry is a major employer" ("Blair ally in poll threat to Bush," The Guardian, November 17, 2003).

${ }^{33}$ The swing states are: in 1988, California, Illinois, Maryland, Missouri, New Mexico, New York, Oregon, Pennsylvania, Vermont, Washington, West Virginia, and Wisconsin; in 1992, Arizona, Colorado, Florida, Georgia, Kentucky, Louisiana, Montana, Nevada, New Hampshire, New Jersey, North Carolina, Ohio, South Dakota, Tennessee, Texas, Virginia, and Wisconsin; in 1996, Arizona, Colorado, Georgia, Kentucky, Montana, Nevada, North Carolina, South Dakota, Tennessee, Texas, and Virginia; in 2000, Florida, Iowa, Minnesota, Missouri, Nevada, New Hampshire, New Mexico, Ohio, Oregon, Pennsylvania, Tennessee, and Wisconsin; in 2004, Colorado, Iowa, Michigan, Minnesota, Nevada, New Hampshire, New Mexico, Ohio, Oregon, Pennsylvania, and Wisconsin; in 2008, Florida, Indiana, Missouri, Montana, North Carolina, and Ohio; in 2012, Florida, North Carolina, Ohio, and Virginia; in 2016, Arizona, Colorado, Florida, Maine, Michigan, Minnesota, Nevada, New Hampshire, North Carolina, Pennsylvania, and Wisconsin. Elections data are retrieved from Dave Leip's Atlas of U.S. Presidential Elections.
} 


\section{Figure 2}

Swing states during the last eight presidential terms

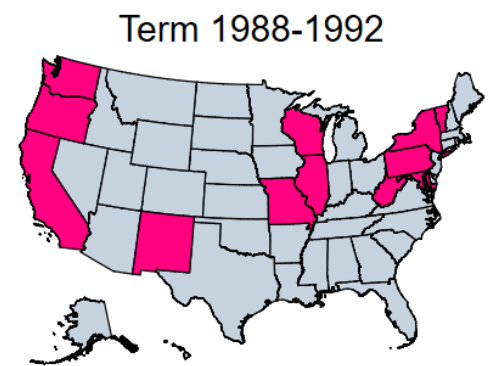

Term 2000-2004

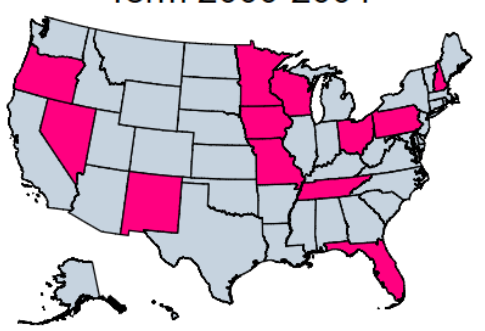

Term 2012-2016

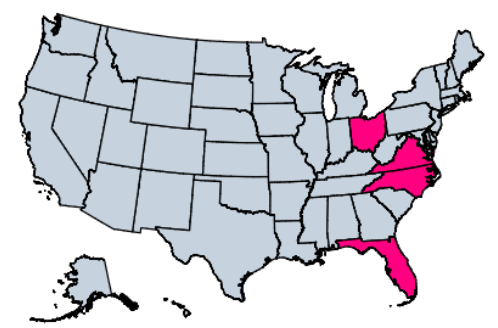

Term 1992-1996

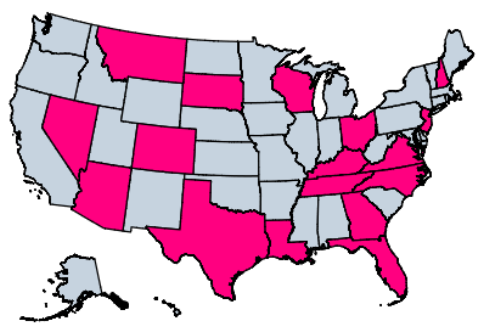

Term 2004-2008

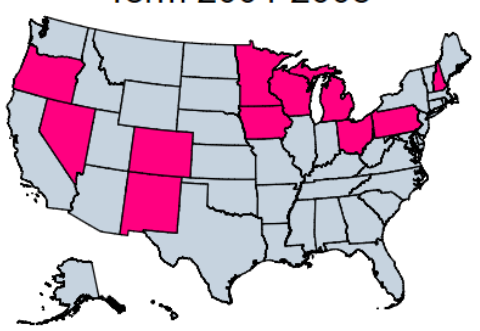

Term 2016-2020

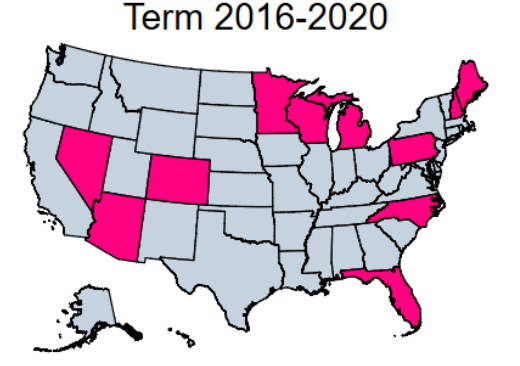

Term 1996-2000

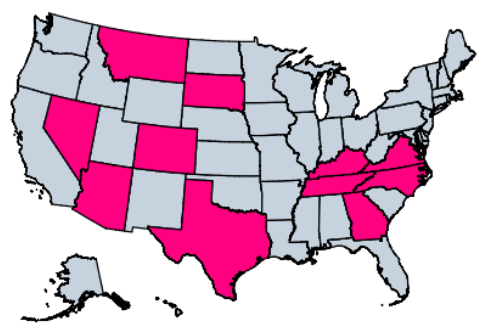

Term 2008-2012

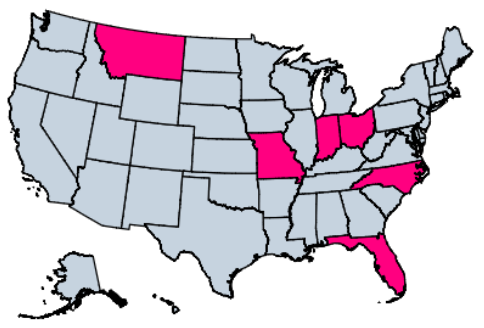

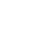

The maps indicate in pink the states classified as swing (less than $5 \%$ difference in the vote shares of Democratic and Republican candidates) during the last eight presidential terms, based on the previous presidential elections.

Our identification strategy relies on the assumption that the identity of swing states is exogenous to trade policy, i.e. AD duties do not affect whether or not the difference in vote shares between the Democratic and Republican candidates is below a certain threshold. In line with this assumption, we have verified that an increase in state-level AD protection during a presidential term has no significant effect on the identity of swing states at the end of that term. ${ }^{34}$ Using the standard retrospective definition of swing states, which is based on vote shares in the previous presidential elections, further dismisses concerns about the validity of our assumption.

To capture heterogeneity in the geographical distribution of industries, we use CBP data

\footnotetext{
${ }^{34}$ To this purpose, we have constructed a measure of $\mathrm{AD}$ protection at the state level: Tariff $_{s, T}=$ $\sum_{i} \alpha_{i, s}$ Tariff $_{i, T}$, where Tariff $_{i, T}$ is the AD duty applied on Chinese imports in industry $i$ in the last year of term $T$ and $\alpha_{i, s}$ is the 1988 share of employment in industry $i$ in state $s$. We have then examined whether changes in state-level AD protection during a term (captured by $\Delta A D_{s, T}$ ) affect the probability that a state is classified as swing at the end of that term (captured by Swing State $_{s, T}$ ). The coefficient of $\Delta$ Tariff $_{s, T}$ was insignificant, confirming that AD duties do not affect the identity of swing states.
} 
on state-level employment shares. To dispel the concern that these shares might be affected by trade protection, we use data from 1988, the first year of our sample period. ${ }^{35}$ To measure the importance of an industry $i$ in states classified as swing during a presidential term $T$, we construct the following variable:

$$
\operatorname{Swing}_{i, T}=\frac{\sum_{s} L_{s, i}^{1988} \times \text { Swing }_{s, T}}{\sum_{s} \sum_{i} L_{s, i}^{1988} \times \operatorname{Swing}_{s, T}}
$$

This is the ratio of the total number of workers employed in industry $i$ in states that are classified as swing during electoral term $T$, over total employment in swing states. ${ }^{36}$.

The variable Swing $_{i, T}$ captures exogenous variation in the political importance of an industry. It exploits changes in the importance of states across electoral terms driven by swing-state politics $\left(\right.$ Swing $\left._{s, T}\right)$ and differences in the importance of industries across states, driven by the initial employment shares $\left(L_{s, i}^{1988}\right) \cdot{ }^{37}$ Descriptive statistics of the variable Swing $_{i, t}$ are reported in Table A-3. The bottom panel of Table A-4 lists the top-10 SIC4 sectors with the highest average value of Swing $_{i, t}$ during 1988-2016.

Using data on state-level employment shares also allows us to compare the location of industries based on their position in the supply chain. This reveals that final good industries are more geographically dispersed than input industries. ${ }^{38}$ This pattern is illustrated by Figure A-6 in the Appendix, which illustrates the geographical distribution across US states of two industries: SIC 3312 ("Blast furnaces and steel mills") and SIC 1510 ("Construction"). The map on the left shows that steel is highly geographically concentrated: three states in the Rust Belt (Indiana, Ohio, and Pennsylvania) account for more than $56 \%$ of US employment in steel, though their share of overall US employment is only $13 \%$; the other states have little or no employment in steel. ${ }^{39}$ The map on the right is for construction, a large non-manufacturing sector that relies heavily on steel as an input (SIC 3312 is the most important input for SIC 1510). Notice that this industry is much more geographically dis-

\footnotetext{
${ }^{35}$ Using data from later years would yield very similar results, given that the geographical distribution of industries across states is stable over time. This can be seen in Figure A-5, which plots state-level employment shares by SIC4 industry in 1988 and 2011, using data from Acemoglu et al. (2016). The correlation between the shares in these two years is 0.96 .

${ }^{36} \mathrm{We}$ construct $S w i n g_{i, T}$ based on employment in all tradable sectors (the only ones that can receive AD protection). In robustness checks, we define the variable over the total number of workers in all sectors

${ }^{37} \mathrm{We}$ have also constructed the variable Downstream Swing $g_{i, T}=\sum_{j} \omega_{i, j} \operatorname{Swing}_{j, T}$. This captures the political importance of downstream industries (i.e. industries $j$ that use $i$ as an input). As discussed below, this variable was never significant when included in our regressions.

38 The correlation between the measure of industry "upstreamness" developed by Antràs et al. (2012) and the index of industry spatial concentration of Ellison and Glaeser (1997) is 0.24 (significant at the 1\% level).

${ }^{39}$ The mean ratio of state-level shares of US employment in steel over state-level shares of total US employment is 0.697. For Indiana, Ohio, and Pennsylvania, this ratio is respectively 6.54, 4.69 and 3.16.
} 
persed: construction is present in all US states, and state-level employment in construction is generally proportional to the total number of workers in the state. ${ }^{40}$

Swing-state politics can shape AD protection by affecting the decisions of the DOC and the ITC, the two key institutions involved in AD policy in the United States. As explained in Section 3, the DOC determines whether a product has been sold at "less than the fair value" and computes the "dumping margin," while the ITC determines whether this "unfair practice" has caused material injury to the US industry.

Political considerations can directly affect decisions of the DOC, which is part of the executive branch. The President nominates the top positions in this department (Secretary, Deputy Secretary), as well as the key positions in charge of AD (e.g. Under Secretary for International Trade, Assistant Secretary for Market Access and Compliance). ${ }^{41}$ Through these political appointments, the White House can shape AD decisions of the DOC. In some cases, the executive directly intervenes in these decisions. ${ }^{42}$

Previous studies show that politics can also affect AD decisions of the ITC commissioners, who are not independent "bureaucrats" simply following technical rules. In particular, these studies show that ITC votes reflect the interests of the members of the two most powerful committees dealing with trade policy in Congress (the Finance committee in the Senate and the Ways and Means committee in the House). Moore (1992) finds that ITC commissioners are more likely to favor AD petitions involving the constituencies of Finance committee members. Hansen and Prusa (1997) show that the ITC is more likely to support petitions filed by industries with representatives in the Ways and Means committee. Aquilante (2018) emphasizes the role of party politics, showing that ITC commissioners appointed by the Democratic (Republican) party are more likely to vote in favor of $\mathrm{AD}$ when the petitioning industry is key (in terms of employment) in the states represented by Democratic (Republican) senators in the Finance committee.

In Section A-1 of the Appendix, we provide additional evidence that politics - and in particular swing-state politics - influences AD decisions by the ITC. First, we find that congressmen from swing states are overrepresented in the Finance and Ways and Means

\footnotetext{
${ }^{40}$ The mean ratio of state-level shares of US employment in construction over state-level shares of total US employment is 0.998 . The maximum ratio is 1.69 (for Maryland).

${ }^{41}$ These appointees must be confirmed by the Senate. Several other lower-ranked positions involved in AD decisions (e.g. Deputy Assistant Secretary for Enforcement and Compliance) are usually politically appointed, but do not require confirmation by the Senate.

${ }^{42}$ For example, in 2017 the DOC reversed its prior negative position on an AD case involving imports from Korea of oil country tubular goods, a type of steel product used in oil fields, after Peter Navarro, Director of the National Trade Council under Trump, sent a "Recommendation for Action" letter requesting a minimum $36 \%$ import duty (see US Court of International Trade, Consol. Court No. 17-00091).
} 
congressional committees, which can put pressure on ITC commissioners through various channels (e.g. appointment confirmations, budget allocation, oversight hearings). More importantly, using detailed data on ITC votes from Aquilante (2018), we show that ITC commissioners are more likely to vote in favor of AD when the petitioning industry is important in swing states (as proxied by the variable $\operatorname{Swing}_{i, T}$ ). These results indicate that, when looking at industries that have experience at filing for AD protection, protection is skewed towards those that are more politically important.

\subsection{Predicting AD Protection}

In what follows, we show that our IV strategy allows us to predict AD protection. Since our instrument varies at the presidential-term level, we consider four-year terms as the time dimension of the panel and estimate the following regression by ordinary least squares (OLS):

$$
\operatorname{Tariff}_{i, T}=\beta_{0}+\beta_{1}+I V_{i, T}+\delta_{i}+\delta_{T}+\varepsilon_{i, T},
$$

where $\operatorname{Tariff}_{i, T}$ measures AD duties on imports from China in SIC4 industry $i$ in force at the end of term $T$. We include sector fixed effects $\left(\delta_{i}\right)$ defined at the SIC4 level to account for any time-invariant sector characteristic that may affect the level of protection, as well as term fixed effects $\left(\delta_{T}\right)$ to control for general macroeconomic and political conditions. In line with earlier studies (e.g. Acemoglu et al., 2016; Pierce and Schott, 2016), we weight regression estimates by start-of-period (1988) industry employment. ${ }^{43}$ We cluster standard errors at the SIC3 level (221 industries) to allow for correlated industry shocks.

The results of estimating (6) are reported in column 1 of Table 1 . The dependent variable is our baseline measure of AD protection against China ( $\operatorname{Tariff}_{i, T}$ ). The coefficient of $I V_{i, T}$ is positive and significant at the 1 percent level, indicating that our instrument is a good predictor of the level of AD protection granted to a SIC4 industry during an electoral term.

Combining the two components of the instrument is key to predicting AD protection. To verify this, notice that Experience $_{i}$ is time invariant, and thus cannot explain within-industry variation in Tariff $f_{i, T}$ across electoral terms. Similarly, the variable Swing $_{i, T}$ cannot by itself explain changes in $\mathrm{AD}$ protection. This can be seen looking at the results in columns 2 and 3 of Table (6), in which we regress Tariff $_{i, T}$ on $\operatorname{Swing}_{i, T}$, first by itself and then with

\footnotetext{
${ }^{43}$ This accounts for the heterogeneity in the size of SIC4 industries. The results are unaffected if we estimate unweighted linear regressions.
} 
$I V_{i, T} \cdot{ }^{44}$ The coefficients of Swing $_{i, T}$ are not statistically significant, while the coefficient of $I V_{i, T}$ remains significant at the $1 \%$ level (and is not statistically different from the coefficient reported in column 1). These results confirm that politically important industries benefit from a higher level of protection, but only if they have long-term knowledge of the complex procedures to petition for $\mathrm{AD}$ duties.

\section{Table 1}

Predicting AD protection

\begin{tabular}{lccc}
\hline \hline & $(1)$ & $(2)$ & $(3)$ \\
\hline$I V_{i, T}$ & $1.398^{* * *}$ & & $1.362^{* * *}$ \\
& $(0.268)$ & & $(0.191)$ \\
Swing $_{i, T}$ & & 8.006 & 1.199 \\
& & $(5.644)$ & $(4.228)$ \\
SIC4 FE & Yes & Yes & Yes \\
Term FE & Yes & Yes & Yes \\
Adjusted $R^{2}$ & 0.57 & 0.54 & 0.57 \\
Observations & 2,835 & 2,835 & 2,835 \\
\hline \hline
\end{tabular}

The table reports OLS estimates. The dependent variable is Tariff $f_{i, T}$, the average AD duty on imports from China in SIC4 industry $i$ in force at the end of term $T$. The sample covers 1988-2016. Observations are weighted by 1988 employment. Standard errors are clustered at the SIC3 industry level; ***, **, and * denote significance at the $1 \%, 5 \%$, and $10 \%$ levels respectively.

In line with this idea, sectors such as "Motor vehicle parts and accessories" (SIC 3714) and "Blast furnaces and steel mills" (SIC 3312), which are often politically important (high average Swing $_{i, T}$ ) and are experienced in filing for AD in the 1980s (high Experience $_{i}$ ), receive high levels of protection (the average AD duties on these industries are respectively $143 \%$ and $82 \%$ ). By contrast, industries with high average $S w i n g_{i, T}$ but no prior experience in $\mathrm{AD}$ filings receive little or no AD protection. This is the case, for example, of "Search and navigation equipment" (SIC 3812).

We carry out a series of additional estimations to verify the robustness of our IV strategy. In columns 1-2 of Table 2, we estimate (6) using the alternative measures of AD protection defined in Section 4.2 (Product Coverage $_{i, T}$ and Import Coverage ${ }_{i, T}$ ). The coefficient of $I V_{i, T}$ remains positive and significant at the 1\% level. Columns 3 and 4 show that our results continue to hold if we include all TTBs (AD, countervailing duties, safeguards) applied

\footnotetext{
${ }^{44}$ Experience $_{i}$ cannot be included in these specifications since it is absorbed by the SIC4 fixed effects.
} 
against China and if we consider AD measures against all countries. ${ }^{45}$ As already pointed out in previous studies (e.g. Blonigen, 2006), steel is the industry that files the highest number of $\mathrm{AD}$ petitions. It is also the industry featuring the highest average $I V_{i, T}$ during our sample period. In column 5 , we show that our instrument continues to work if we exclude this industry.

Table 2

Predicting AD protection

\begin{tabular}{lccccc}
\hline \hline & $\begin{array}{c}\text { Product } \\
\text { coverage } \\
(1)\end{array}$ & $\begin{array}{c}\text { Import } \\
\text { coverage }\end{array}$ & All TTBs & All countries & No steel \\
& $0.110^{* * *}$ & $0.017^{* * *}$ & $1.333^{* * *}$ & $0.623^{* * *}$ & $3.314^{* * *}$ \\
\hline$I V_{i, T}$ & $(0.022)$ & $(0.003)$ & $(0.278)$ & $(0.195)$ & $(1.227)$ \\
SIC4 FE & Yes & Yes & Yes & Yes & Yes \\
Term FE & Yes & Yes & Yes & Yes & Yes \\
Adjusted $R^{2}$ & 0.69 & 0.44 & 0.57 & 0.62 & 0.55 \\
Observations & 2,835 & 2,835 & 2,835 & 2,835 & 2,835 \\
\hline \hline
\end{tabular}

The table reports OLS estimates. In columns 1-2, the dependent variable is one of the alternative AD measures

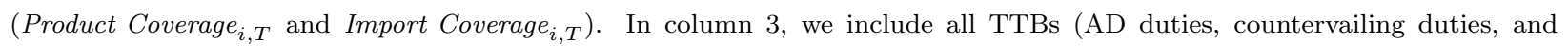
safeguards) applied by the United States against China to construct Tariff ${ }_{i, T}$. In column 4 , we consider AD duties applied by the United States against all countries. In column 5, we exclude the steel industry (SIC 3312). The sample covers $1988-2016$. Observations are weighted by 1988 employment. Standard errors are clustered at the SIC3 industry level; ***, **, and * denote significance at the $1 \%, 5 \%$, and $10 \%$ levels respectively.

A second set of robustness checks is reported in Table 3. In columns 1-3, we consider alternative definitions of swing states to construct $I V_{i, T}$. The variable $S w i n g_{i, T}$ defined in equation (5) already takes into account differences in the size of swing states with respect to their workforce. In column 1, we further account for heterogeneity across swing states, weighting the dummy variable Swing State $_{s, T}$ by the number of electoral votes assigned to each swing state $s$ in term $T .{ }^{46}$ In our baseline estimations, we follow the literature in classifying a state to be swing if the difference in vote shares of the candidates from two

\footnotetext{
${ }^{45}$ When including all countries, we first compute $\mathrm{AD}$ duties at the country-industry-term level. We then define Tariff $_{i, T}$ as the maximum duty among all targeted countries. We take the maximum to make sure that the high duties often imposed on the largest exporters of a product are not dampened by the much lower duties imposed on smaller targets.

${ }^{46}$ The Electoral College is a body of electors established by the US Constitution, which forms every four years to elect the president and vice president of the United States. It consists of 538 electors, and an absolute majority of electoral votes (270 or more) is required to win the election. Data on the number of electors come from Dave Leip's Atlas of U.S. Presidential Elections.
} 
main political parties in the previous presidential elections is less than $5 \%$. In column 2 , we increase the threshold to $10 \%$. This definition leads us to classify many more states as swing (22 on average), decreasing the accuracy of our instrument. ${ }^{47}$

Table 3

Predicting AD protection

\begin{tabular}{lccccc}
\hline \hline & $\begin{array}{c}\text { Electoral } \\
\text { votes }\end{array}$ & $\begin{array}{c}10 \% \\
\text { threshold }\end{array}$ & $\begin{array}{c}\text { Next } \\
\text { elections }\end{array}$ & $\begin{array}{c}\text { Alternative } \\
\text { Experience }_{i}\end{array}$ & $\begin{array}{c}\text { Alternative } \\
\text { Swing }_{i, T} \\
\end{array}$ \\
& $(1)$ & $(2)$ & $(3)$ & $(4)$ & $(5)$ \\
\hline$I V_{i, T}$ & $1.137^{* * *}$ & $2.112^{* *}$ & $0.758^{* * *}$ & $1.240^{* * *}$ & $5.532^{* * *}$ \\
SIC4 FE & $(0.203)$ & $(1.038)$ & $(0.220)$ & $(0.246)$ & $(1.072)$ \\
Term FE & Yes & Yes & Yes & Yes & Yes \\
Adjusted $R^{2}$ & Yes & Yes & Yes & Yes & Yes \\
Observations & 0.57 & 0.54 & 0.55 & 0.57 & 0.57 \\
\hline \hline
\end{tabular}

The table reports OLS estimates. The dependent variable is Tariff ${ }_{i, T}$, the average AD duty on imports from China in SIC4 industry $i$ in force at the end of term $T$. In column 1, the variable $S w i n g_{i, T}$ used to construct $I V_{i, T}$ is constructed weighting each swing state by its number of electors. In column 2, swing states are defined based on the outcome of the previous presidential elections ( $10 \%$ difference in vote shares between the Democratic and Republican candidates), while in column 3 they are defined on the outcome of the next presidential elections ( $5 \%$ difference in vote shares). In column 4 , we use an alternative definition of Experience $_{i}$ (which accounts for all petitions in 1980-1987) to construct $I V_{i, T}$. In column 5 , we use an alternative definition of the variable Swing $_{i, T}$ (based on total employment in swing states). The sample covers 1988-2016. Observations are weighted by 1988 employment. Standard errors are clustered at the SIC3 industry level; ***,**, and * denote significance at the $1 \%$, $5 \%$, and $10 \%$ levels respectively.

Our retrospective definition ensures that the identity of swing states is not affected by trade policy, but does not take into account new information that politicians may acquire during a term on the identity of battleground states in the next elections. In column 3, we keep the standard 5\% threshold, but define swing states based on the outcome of the next presidential elections. Recall that the variable Experience ${ }_{i}$ used to construct $I V_{i, T}$ excludes all AD petitions targeting China and leading to measures in force during our sample period. In column 4, we use a different definition of Experience ${ }_{i}$, which is the number of all AD petitions filed by SIC4 industry $i$ during 1980-1987, including those leading to measures in force after 1987 (but still excluding petitions targeting China). Finally, our baseline definition of Swing $_{i, T}$ is the ratio of total employment in industry $i$ in states classified as swing during

\footnotetext{
${ }^{47}$ For example, using this definition, California is classified as swing in the 2004 presidential elections, given that the difference in vote shares in the state was $9.9 \%$. We have also tried to use a threshold of $2.5 \%$, which produced an insignificant coefficient. This is not surprising given that this lower threshold can lead us to mistakenly classify several states as "safe." For example, in the 2008 presidential elections, the differences in vote shares in battleground Ohio and Florida were respectively $4.6 \%$ and $2.8 \%$, and they are excluded from the set of swing states when one uses the restrictive $2.5 \%$ threshold.
} 
term $T$, over total employment in those states in tradable industries. In column 5, we construct our instrument using a different definition of $S w i n g_{i, T}$ based on employment in all industries. ${ }^{48}$ Across all specifications, the coefficient of $I V_{i, T}$ is positive and significant, confirming that our instrument is a strong predictor of AD protection. ${ }^{49}$

\subsection{Placebo Tests}

Our instrument $I V_{i, T}$ combines pre-sample variation in the ability of industries to petition for $\mathrm{AD}$ protection with variation in the political importance of industries across electoral terms. The logic of the instrument is that $\mathrm{AD}$ duties should be skewed in favor of important industries in swing states (high Swing $_{i, T}$ ), but only if they have experience at petitioning for $\mathrm{AD}$ (i.e. positive Experience $e_{i}$ ). Notice that the time variation in our instrument comes from changes in the identity of swing states, which are captured by the dummy variable Swing $_{s, T}$ as illustrated in Figure 2.

To verify the logic behind our identification strategy, we perform some placebo tests using randomized distributions of swing states to construct the variable Swing $_{s, T}$ and our instrument $I V_{i, T}$. First, we examine whether the identity of swing states is key for predicting $\mathrm{AD}$ protection. Within each presidential term, we randomly choose the swing states across all 50 US states. ${ }^{50}$ We perform 5,000 randomizations. Each randomization consists of independent random draws of swing states, one per presidential term. From each randomization, we obtain a variable Placebo Swing $_{s, T}$, which we use to construct our placebo instrument and estimate the following: ${ }^{51}$

$$
\text { Tariff }_{i, T}=\beta_{0}+\beta_{1} \text { Placebo } I V_{i, T}+\delta_{i}+\delta_{T}+\varepsilon_{i, T}
$$

Panel (a) of Figure 3 shows the distribution of the 5,000 estimated $\beta_{1}$ coefficients with their 99\% confidence intervals. Notice that randomizing the identity of swing states produces a wide range of coefficients (from -4.27 to 2.21 ), and the mean of the distribution is negative (-

\footnotetext{
${ }^{48}$ We have also tried to include in equation (6) the variable Downstream Swing $_{i, T}$ defined in footnote 37. The coefficient of this variable was never significant.

${ }^{49}$ Unlike other trade policies (e.g. safeguards or the initiation of trade disputes), AD is not directly controlled by the executive. Still, whether the president can be re-elected or is a "lame duck" may affect the power of our instrument. In all our regressions, we include term fixed effects to control for re-election motives. If we estimate (6) separately to predict $\mathrm{AD}$ measures during first and second terms, the coefficients of $I V_{i, T}$ are positive and significant in both samples (results available upon request).

${ }^{50}$ The number of swing states in a given term is kept as in Figure 2. For example, we randomly choose six states for the presidential term 2008-2012 and four states for 2012-2016.

${ }^{51}$ The variable Placebo $I V_{i, T}$ is constructed by replacing the dummy variable Swing State $_{s, T}$ in equation (5) with Placebo Swing s $_{s, T}$.
} 
0.14). The red cross corresponds to the estimated coefficient (1.398) in our baseline regression in column 1 of Table 1 . It is significant at the $1 \%$ level, and is out of the $99 \%$ confidence interval of the placebo estimates [-2.08 - 1.30]. This exercise shows that using the actual identity of swing states is key for predicting AD protection.

\section{Figure 3}

Estimated coefficients of Placebo $I V_{i, T}$

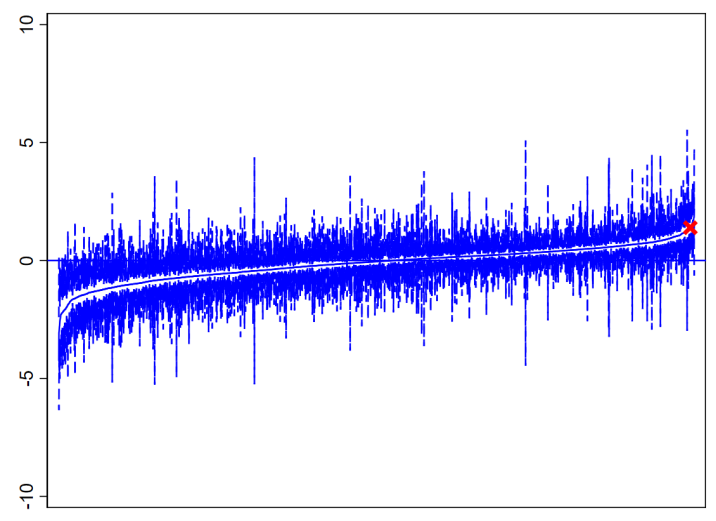

(a)

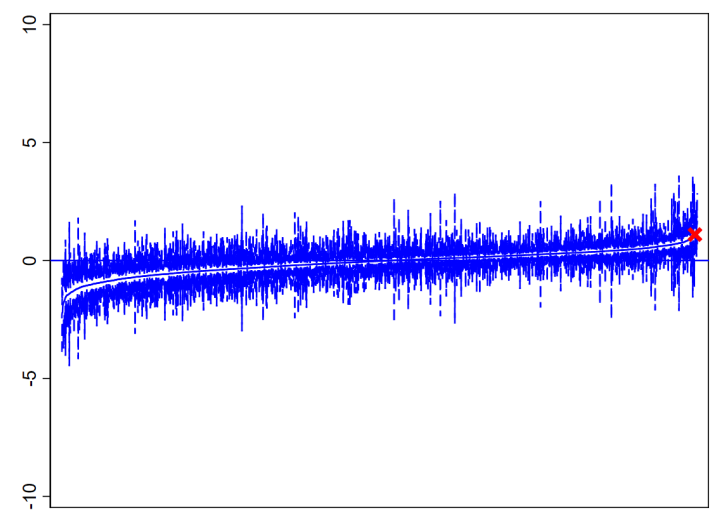

(b)

The figure plots the coefficients of Placebo $I V_{i, T}$ (with $99 \%$ confidence intervals) obtained from performing 5,000 randomizations of the swing states and estimating (7). In panel (a), the swing states in a presidential term are randomly chosen out of the 50 states, while in panel (b) they are chosen across those states that were classified as swing at least once during the last eight presidential terms. The red cross corresponds to the estimated coefficient in our baseline first-stage regression (column 1 of Table 1).

In a second placebo test, we investigate whether the time-varying nature of swing states matters. We perform 5,000 randomizations across those states that were classified as swing at least once during the last eight presidential terms. Panel (b) of Figure 3 plots the distribution of the 5,000 estimated $\beta_{1}$ coefficients based on this alternative randomization. These coefficients vary widely (from -3.06 to 2.11) and have a negative mean (-0.11). Again, our benchmark estimate as indicated by the red cross is out of the $99 \%$ confidence interval of the placebo estimates [-1.83 - 1.17]. This exercise shows that predicting AD protection requires a time-varying instrument, which keeps track of changes in the identity of swing states across electoral terms. 


\section{$6 \quad$ Effects of Protection Along Supply Chains}

\subsection{The Effects on Employment in Downstream Industries}

The goal of our analysis is to identify the impact of protection along supply chains. To this purpose, we exploit time-series and cross-sectional variation in AD protection against China during the seven presidential terms covering 1988-2016. In line with previous studies on the "China Syndrome" (e.g. Autor et al., 2013; Acemoglu et al., 2016; Pierce and Schott, 2016), our main focus is on employment.

We first construct instruments for input duties in force against China at the end of each term $T$ :

$$
\text { IV Average Input Tariff } f_{j, T}=\sum_{i=1}^{N} \omega_{i, j} \text { Experience }_{i} \times \text { Swing }_{i, T},
$$

$$
\text { IV Tariff on Key } \text { Input }_{j, T}=\text { Experience }_{1, j} \times \text { Swing }_{1, j, T},
$$

where $\omega_{i, j}$ denotes the direct requirement coefficient for the sector pair $i j$ and $1, j$ denotes the most important input in the production of $j$ (with highest $\omega_{i, j}$ ).

We then estimate two-stage least squares (2SLS) regressions in differences:

$$
\Delta L_{j, T}=\beta_{0}+\beta_{1} \Delta \text { Input } \text { Tariff }_{j, T}+\delta_{j}+\delta_{T}+\varepsilon_{j, T} .
$$

The dependent variable $\Delta L_{j, T}$ is the annualized growth rate in employment in SIC4 industry $j$ during term $T .{ }^{52} \Delta$ Input Tariff $_{j, t}$ is the change in the average input tariff faced by industry $j$ (or in the tariff on the key input of industry $j$ ) during term $T$, instrumented using $\Delta I V$ Average Input Tariff $f_{j, T}$ (or using $\Delta I V$ Tariff on Key Input $_{j, T}$ ). We include industry fixed effects at the SIC4 level $\left(\delta_{j}\right)$ to control for sectoral trends and term fixed effects $\left(\delta_{T}\right)$ to control for differences in macroeconomic and political conditions across terms. We weight observations by start-of-period industry employment, and cluster the standard errors at the SIC3 level to allow for correlated industry shocks.

Estimating regressions in differences rather than levels allows us to control for sectoral trends and account for other determinants of employment growth. As discussed below, this estimation strategy also allows us to carry out a counterfactual exercise similar to that of

\footnotetext{
${ }^{52}$ For term $T$ ending in year $t, \Delta L_{j, T}=\left(\ln \left(\right.\right.$ Employment $\left._{j, t}\right)-\ln \left(\right.$ Employment $\left.\left._{j, t-4}\right)\right) / 4$.
} 
Acemoglu et al. (2016) to compute the number of jobs lost due to trade protection. ${ }^{53}$

It should be stressed that our 2SLS estimates capture local average treatment effects, i.e. the effect of the treatment $\left(I V_{i, T}\right)$ for the "compliers," the subset of the sample that takes the treatment if and only if they were assigned to it (Imbens and Angrist, 1994). We are thus capturing the effects of protectionist measures that are driven by the joint effect of AD experience and swing-state politics.

Table 4 reports the results of estimating (10). In columns 1 and 2, we consider all industries, while in columns 3 and 4 we restrict the analysis to manufacturing industries. In

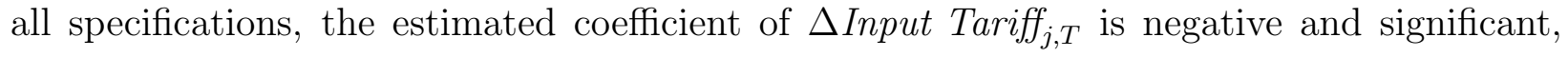
indicating that higher tariffs in upstream industries hamper employment growth in downstream industries. Comparing across the specifications of Table 4, notice that the estimated coefficients of $\Delta$ Input Tariff $_{j, T}$ are larger when including non-manufacturing industries.

\section{Table 4}

The impact of tariffs on employment in downstream industries

\begin{tabular}{lcccc}
\hline \hline & \multicolumn{2}{c}{ All sectors } & \multicolumn{2}{c}{ Manufacturing sectors only } \\
& Average input & Tariff on key & Average input & Tariff on key \\
& tariff & input & tariff & input \\
& $(1)$ & $(2)$ & $(3)$ & $(4)$ \\
\hline S Input Tariff $j_{j, T}$ & $-0.319^{* * *}$ & $-0.042^{* * *}$ & $-0.151^{* * *}$ & $-0.019^{* * *}$ \\
& $(0.087)$ & $(0.008)$ & $(0.053)$ & $(0.007)$ \\
SIC4 FE & Yes & Yes & Yes & Yes \\
Year FE & Yes & Yes & Yes & Yes \\
Observations & 3,351 & 3,351 & 2,742 & 2,742 \\
KP F-statistic & 229.1 & $1,349.8$ & 163.6 & 715.5 \\
\hline \hline
\end{tabular}

The table reports 2SLS estimates. The dependent variable $\Delta L_{j, T}$ is the annualized log change in employment in SIC4 industry $j$ during term T. $\Delta$ Input $_{\text {Tariff }_{j, T}}$ is the change in the average input tariff of industry $j$ (in columns 1 and 3 ) or in the tariff on the key input of industry $j$ (in columns 2 and 4) during term $T$. The sample covers 1988-2016. In columns 1 and 2 (3 and 4), it comprises all sectors (only manufacturing sectors). Observations are weighted by 1988 employment. Standard errors are clustered at the SIC3 industry level; ***, **, and * denote significance at the $1 \%, 5 \%$, and $10 \%$ levels respectively.

The last row of Table 4 reports the Kleibergen-Paap (KP) F-statistics, which indicate that we can reject the hypothesis that our instrument is weak. ${ }^{54}$ In the top panel of Table

\footnotetext{
${ }^{53}$ In robustness checks, we report the results of 2 SLS regressions in which we estimate the effect of AD protection on the level of employment in downstream industries. These specifications do not control for sectoral trends and do not allow us to compute counterfactual employment changes.

${ }^{54}$ The KP statistic is a version of the Cragg-Donald statistic adjusted for clustered robust standard errors. The statistics in Table 4 are all above the critical value of 16.4 (9.0) based on a 10\% (15\%) maximal IV size.
} 
A-8 of the Appendix, we show the first-stage results of the 2SLS regressions in Table 4. The coefficient of our instrument is positive and significant at the $1 \%$ level in all specifications. In the bottom panel of the same table, we report the reduced-form results. As expected, the coefficient of $\Delta I V_{j, T}$ is always negative and significant.

We can compare the results of the 2SLS regressions in Table 4 with the corresponding results of OLS regressions. As shown in Table A-9, if we ignore the endogeneity of trade policy, the estimated coefficient for input protection is negative but not significant in most specifications. The negative $\beta_{1}$ coefficient becomes larger in magnitude (and statistically significant) when instrumenting for input tariffs. In line with the discussion in Section 5.1, these results suggest that omitted variables generate a positive bias in the OLS estimates, which makes it harder to identify negative effects of upstream protection on employment growth in downstream industries.

In terms of magnitude, the baseline estimate reported in column 1 of Table 4 implies that a one percentage point increase in the average input tariff leads to a 0.32 percentage point decrease in the annual growth rate of employment in downstream industries. Alternatively, a one standard deviation (0.022) increase in the predicted average input tariff decreases the yearly employment growth by 0.71 percentage points, which explains $16.3 \%$ of the standard deviation of employment growth during 1988-2016.

To quantify the number of jobs lost due to input protection, we apply the methodology proposed by Acemoglu et al. (2016) and perform the following counterfactual exercise:

$$
\text { Employment Losses }=\sum_{j, T} L_{j, T}\left(1-e^{-\hat{\beta}_{1} \Delta \tilde{\tau}_{j, T}}\right)
$$

where $L_{j, T}$ is the employment level in industry $j$ at the end of term $T, \hat{\beta}_{1}$ is the estimated coefficient of $\Delta$ Input Tariff $_{j, T}$ in the second stage, and $\Delta \widetilde{\tau}_{j, T}$ is the actual change in the average input tariff, weighted by the partial $R^{2}$ in the first stage. To carry out this counterfactual exercise, we use the baseline estimates in column 1 of Table $4 .^{55}$

The results of this exercise imply that around 1,850,000 US jobs were lost across all industries due to input protection. This figure corresponds to $4.8 \%$ of the 38 million jobs the US economy added during 1988-2016. The effects are smaller (around 280,000 jobs lost) if we use the estimates in column 3 of Table 4, which restricts the analysis to manufacturing downstream industries.

\footnotetext{
${ }^{55}$ In this specification, the partial $R^{2}$ in the first stage is 0.139 . Notice that Acemoglu et al. (2016) apply this counterfactual exercise to their baseline specification, which does not control for SIC4 sectoral trends. Our counterfactual estimates are very similar if we de-trend industry employment.
} 


\subsection{Robustness Checks}

The main result of our analysis is that increases in input tariffs lead to significant declines in employment growth in downstream sectors. We have carried out a series of additional estimations to verify the robustness of this finding. The results can be found in Section A-4 of the Appendix. In the interest of space, we focus on the baseline specifications corresponding to column 1 of Table 4.

In Table A-12, we verify that the results are robust to using alternative AD measures. In columns 1 and 2, we use the variables Product Coverage ${ }_{i, T}$ and Import Coverage ${ }_{i, T}$ to estimate (10). The coefficient of $\Delta$ Input $\operatorname{Tariff}_{j, T}$ remains positive and significant at the $1 \%$, confirming that $\mathrm{AD}$ protection reduces employment growth in downstream sectors. In columns 3 and 4, we show that our results continue to hold if we take into account other TTBs (countervailing duties and safeguards) applied by the US against China ${ }^{56}$ and consider the effects of US AD duties against all countries.

In Table A-13, we show that our results are robust to controlling for additional tariffs. In column 1 , we control for $\mathrm{AD}$ duties in the downstream industry $j$. Note that in this specification the number of observations is reduced from 3,351 to 2,833 , since the sample includes tradable industries only. The coefficient of $\Delta$ Input $_{\text {Tariff }} j_{j, T}$ remains positive and significant, while the coefficient of $\Delta$ Tariff $_{j, T}$ is not significant. ${ }^{57}$ In column 2 , we include the variable $\triangle$ Input Tariff $M F N_{j, T}$, which captures changes in US MFN tariffs on the inputs of industry $j$. The coefficient of $\Delta$ Input $\operatorname{Tariff}_{j, T}$ remains positive and significant at the $1 \%$ level, while the coefficient of the MFN variable is insignificant. ${ }^{58}$ This is not surprising, since US MFN rates vary little over time, as mentioned in Section 4. In column 2, we control for Chinese AD duties on US goods. Several studies (e.g. Blonigen and Bown, 2003; Feinberg and Reynolds, 2006, 2008) emphasize retaliatory motives in AD filings. To account for possible retaliation effects, we include changes in AD duties applied by China on US input

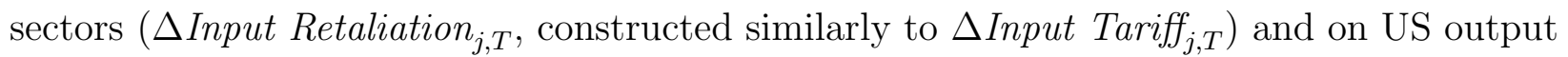

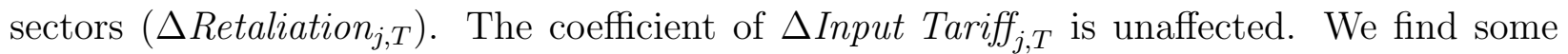
evidence of negative effects of retaliation in input sectors.

In Table A-14 we show that our baseline results are robust to using alternative methods

\footnotetext{
${ }^{56}$ Countervailing duties on China are almost always applied in combination with antidumping duties. When the measures are combined, we compute the average input tariff using the duty determined jointly from the antidumping and countervailing investigations.

${ }^{57}$ In this specification, which includes two endogenous regressors, the critical value for the KP statistic based on a $10 \%$ maximal IV size 7.0.

${ }^{58}$ Our results do not change if instead of MFN tariffs, we use effectively applied tariffs that take into account US preferential tariffs.
} 
to identify vertically-related industries. In our benchmark regressions, we use direct requirement coefficients to construct the input protection variables and focus on the effects of AD duties on vertically-related industries. In columns 1 and 2, we use total requirement coefficients to construct our measures of input tariffs, thus allowing for both direct and indirect vertical linkages. In columns 3 and 4, we include the diagonal of the input-output matrix (i.e. $\left.\omega_{j, j}\right)$ when constructing $\Delta$ Input Tariff $_{j, T}$.

In Table A-15 we report robustness checks related to the political importance of industries. The variable Swing $_{i, T}$ used to construct our instrument for input tariffs is defined as the ratio of the total number of workers employed in industry $i$ in states classified as swing during term $T$, over the total number of workers in tradable sectors in those states. In column 1 of Table A-15, we show that our results are unaffected if we include non-tradable industries when constructing Swing $_{i, T}$. The estimates reported in columns 2-4 show that the results continue to hold if we control for changes in the political importance of input industries $\left(\Delta\right.$ Input $\left._{\text {Swing }}, T\right)$ and of the downstream industry $\left(\Delta\right.$ Swing $\left._{j, T}\right)$.

Finally, in Table A-16, we consider alternative econometric methodologies. Column 1 reports the results of 2SLS regressions in which we estimate the effect of AD protection on the level of employment in downstream industries. The estimates confirm that AD duties have negative effects on employment in downstream industries. The results continue to hold if we change the dependent variable to yearly differences instead of term differences (column 2). In our baseline regressions, we weight regression estimates by start-of-period (1988) industry employment, in line with earlier studies (e.g. Acemoglu et al., 2016; Pierce and Schott, 2016). In column 3, we show that our results are unaffected if we estimate unweighted linear regressions. Finally, in column 4 we cluster standard errors using broader (58) industry clusters at the SIC2 level.

\subsection{Heterogeneous Effects Across Industries}

The effects of input tariffs should vary across downstream sectors: industries that rely more on protected inputs should face higher Average Input Tariff ${ }_{j, T}$ and Tariff on Key Input ${ }_{j, T}$ and suffer larger job losses.

Table A-10 in the Appendix lists the ten downstream industries most negatively affected by input protection. ${ }^{59}$ This includes large non-manufacturing industries, which have faced high tariffs on some of their key inputs. For example, our estimates imply that during 1988-

\footnotetext{
${ }^{59}$ The number of estimated job losses reported in this table is obtained by carrying out the counterfactual exercise in (11) by SIC4 industry.
} 
2016 more than 210,000 additional jobs would have been created in the restaurant industry (SIC 5812) absent AD protection. The average input duty faced by this industry was $13.44 \%$, with duties of $201.6 \%$ and $112.8 \%$ on crawfish and shrimps, respectively. ${ }^{60}$ Another example is construction (SIC 1510), which during our sample period faced an average input tariff of $10.20 \%$, and a tariff on its key input steel of $81.61 \%$. Our estimates imply that average input protection accounts for around 170,000 US jobs lost in the construction industry during this period.

The effects of protection should also depend on the extent to which downstream producers rely on foreign suppliers for their inputs. To verify this, we use data on trade flows and production at the start of our sample period to construct a measure of the proportion of domestic consumption of industry $i$ accounted for by imports from China: Import Penetration ${ }_{i}=$ (Imports from China $\left.{ }_{i, 1991}\right) /\left(\right.$ US Production ${ }_{i, 1991}+U S$ Imports $_{i, 1991}-U S$ Exports $\left._{i, 1991}\right)$. Using the cost shares $\omega_{i, j}$ to capture vertical linkages, we then construct measures of the average import dependence of a downstream industry $j$ :

$$
\text { Import Dependence }_{j}=\sum_{i=1}^{N} \omega_{i, j} \text { Import Penetration } \text {. }_{\text {. }}
$$

This is a conservative measure of the extent to which producers in our sample rely on imports from China, since it is based on trade flows in 1991, before China became a major sourcing country for the United States.

To study the role of import dependence, we estimate the following regression by 2SLS:

$\Delta L_{j, T}=\beta_{0}+\beta_{1} \Delta$ Input Tariff $_{j, T}+\beta_{2} \Delta$ Input Tariff $_{j, T} \times$ High Import Dependence $_{j}+\delta_{j}+\delta_{T}+\varepsilon_{j, T}$,

in which High Import Dependence $e_{j}$ is a dummy variable equal to 1 if Import Dependence ${ }_{j}$ is above the mean level $(0.13 \%)$ or the median level $(0.09 \%)$. The $\beta_{1}$ coefficient captures the effect of input protection on employment in downstream industries that have low dependence on imported inputs, while the sum of the $\beta_{1}$ and $\beta_{2}$ coefficients captures the effect on industries that rely more on imported inputs.

The results of these regressions are reported in Table A-11. They confirm that AD

\footnotetext{
${ }^{60}$ Debaere (2009) studies an AD case filed by the Southern Shrimp Alliance (SSA), which in 2004 led to duties being imposed on shrimp imports from several countries (China, Thailand, Vietnam, India, Brazil, and Ecuador). He notes that eight SSA states were expected to be "political battlegrounds" in the elections, which helps explain why the duties were introduced, notwithstanding strong opposition by US seafood distributors, retailers, restaurateurs, and other businesses involved in shrimp processing and marketing.
} 
protection reduces the growth rate of employment in downstream industries and that this negative effect is stronger for industries that rely more on imported inputs (the F-tests reported at the bottom of the table show that the sum of $\beta_{1}$ and $\beta_{2}$ is significantly different from 0 at the $1 \%$ level).

\subsection{Extending the Analysis to Measures Introduced under Trump}

In our analysis so far, we have focused on the effects of US AD duties against China during the seven complete presidential terms covering the 1988-2016 period. As mentioned in Section 4, since President Trump took office in January 2017, China has been the target of even higher AD protection. Moreover, Trump introduced additional tariffs, which were stacked on top of existing AD duties.

Since the CBP data on industry-level employment is only available until 2018, in Table 5 , we extend our analysis to protectionist measures introduced during the first two years of Trump's presidency. In columns 1-2, we reproduce the specifications of columns 1 and 2 of Table 4, including the AD duties introduced during 2017-2018, while in columns 3-4 we further include all TTBs (AD, CVDs, safeguards) applied against China since 1988, as well as the additional tariffs introduced during Trump's presidency.

\section{Table 5}

The impact of tariffs on employment in downstream industries (including measures introduced during Trump's presidency)

\begin{tabular}{|c|c|c|c|c|}
\hline & \multicolumn{2}{|c|}{ AD only } & \multicolumn{2}{|c|}{ All TTBs + Trump's tariffs } \\
\hline & $\begin{array}{c}\text { Average input } \\
\text { tariff } \\
(1)\end{array}$ & $\begin{array}{c}\text { Tariff on key } \\
\text { input } \\
(2)\end{array}$ & $\begin{array}{c}\text { Average input } \\
\text { tariff } \\
(3)\end{array}$ & $\begin{array}{c}\text { Tariff on key } \\
\text { input } \\
(4)\end{array}$ \\
\hline$\Delta$ Input Tariff $_{j, T}$ & $\begin{array}{c}-0.380 * * * \\
(0.105)\end{array}$ & $\begin{array}{c}-0.048^{* * *} \\
(0.009)\end{array}$ & $\begin{array}{c}-0.485^{* * *} \\
(0.145)\end{array}$ & $\begin{array}{c}-0.055^{* * *} \\
(0.010)\end{array}$ \\
\hline SIC4 FE & Yes & Yes & Yes & Yes \\
\hline Year FE & Yes & Yes & Yes & Yes \\
\hline Observations & 3,829 & 3,829 & 3,829 & 3,829 \\
\hline KP F-statistic & 162.7 & 979.2 & 100.4 & 624.1 \\
\hline
\end{tabular}

The table reports 2SLS estimates. The dependent variable $\Delta L_{j, T}$ is the annualized log change in employment in SIC4 industry $j$ during term T. $\Delta$ Input $_{\text {Tariff }_{j, T}}$ is the change in the average input tariff of industry $j$ (in columns 1 and 3 ) or in the tariff on the key input of industry $j$ (in columns 2 and 4) during term $T$. In columns 1-2, this variable is constructed based on US AD duties against China, while in columns 3-4 it includes all TTBs (AD, CVDs, safeguards) applied against China and the additional tariffs introduced during Trump's presidency. Observations are weighted by 1988 employment. The sample covers 1988-2018. Standard errors are clustered at the SIC3 industry level; ***, **, and * denote significance at the $1 \%, 5 \%$, and $10 \%$ levels respectively. 
The coefficient of $\Delta$ Input Tariff $_{j, T}$ in column 3 implies that a one percentage point increase in the average input tariff leads to a 0.6 percentage point decrease in the annual growth rate of employment in downstream industries. Using this estimate to carry out the counterfactual exercise in equation (11), we find that around 500,000 US jobs were lost across downstream industries due to protectionist measures introduced during the first two years of Trump's presidency.

Recall that the baseline estimates of Table 4 imply that around 1.8 million US jobs were lost across all industries due to input protection, i.e. an average of around 260,000 jobs lost in each of the seven complete presidential terms. The results of Table 5 indicate that the AD duties and other protectionist measures introduced during the first two years of Trump's presidency caused much larger losses along supply chains. Notice that several countries, most notably China, retaliated against Trump's tariffs by raising tariffs on US goods. In unreported results, we find that controlling for these tariffs does not affect the coefficients of $\Delta$ Input Tariff $f_{j, T}$ in Table 5 .

\subsection{Other Outcome Variables}

We next estimate 2SLS regressions to study the effects of protection on other industry outcomes, using data from the NBER-CES Manufacturing Industry Database. In these regressions, we focus on the effects of average input tariffs, as in our baseline specifications of Table 4. A drawback of using the NBER-CES dataset is that it only provides information for manufacturing industries, and only until 2011. This significantly reduces the sample size and does not allow us to study the effects of $\mathrm{AD}$ duties on non-manufacturing industries.

We first examine the impact of input protection on blue- and white-collar jobs. The results are reported in column 1 and 2 of Table 6 . Notice that the number of observations in Table 6 is much smaller than in our baseline specification in column 3 of Table 4 (2,320 instead of 3,351) due to the restricted sector and time coverage of the NBER-CES dataset. The coefficient of $\Delta$ Input Tariff $j_{j, T}$ is negative and significant only in column 1, indicating that $\mathrm{AD}$ duties reduce the growth rate of blue-collar jobs in downstream manufacturing sectors, but have no effect on white-collar jobs. In column 3-5, we examine the impact of input protection on wages, sales, and investment. The coefficient of $\Delta$ Input Tariff $_{j, T}$ is negative and significant in all specifications, indicating that $\mathrm{AD}$ duties reduce the growth rate of all these outcome variables. 


\section{Table 6}

The impact of tariffs on other outcomes in downstream industries

\begin{tabular}{|c|c|c|c|c|c|}
\hline & $\begin{array}{c}\text { Blue Collar } \\
\text { (1) }\end{array}$ & $\begin{array}{c}\text { White Collar } \\
\text { (2) }\end{array}$ & $\begin{array}{c}\text { Wages } \\
(3)\end{array}$ & $\begin{array}{l}\text { Sales } \\
(4)\end{array}$ & $\begin{array}{c}\text { Investment } \\
(5)\end{array}$ \\
\hline$\Delta$ Input Tariff ${ }_{j, T}$ & $\begin{array}{c}-0.143^{* *} \\
(0.065)\end{array}$ & $\begin{array}{c}0.001 \\
(0.040)\end{array}$ & $\begin{array}{c}-0.031^{* *} \\
(0.013)\end{array}$ & $\begin{array}{c}-0.176 * * * \\
(0.054)\end{array}$ & $\begin{array}{c}-0.302^{* *} \\
(0.117)\end{array}$ \\
\hline SIC4 FE & Yes & Yes & Yes & Yes & Yes \\
\hline Year FE & Yes & Yes & Yes & Yes & Yes \\
\hline Observations & 2,320 & 2,320 & 2,320 & 2,320 & 2,320 \\
\hline KP F-statistic & 170.9 & 170.9 & 170.9 & 170.9 & 170.9 \\
\hline
\end{tabular}

The table reports 2SLS estimates. The dependent variable is the annualized log change in the number of blue-collar jobs (column 1), white-collar jobs (column 2), wages (column 3), sales (column 4), and investment (column 5) in SIC4 industry $j$ during term T. $\Delta$ Input Tariff $_{j, T}$ is the change in the average input tariff of industry $j$ during term $T$. The sample covers 1988-2011 and includes only manufacturing downstream sectors. Observations are weighted by 1988 employment. Standard errors are clustered at the SIC3 industry level; ***, **, and * denote significance at the $1 \%, 5 \%$, and $10 \%$ levels respectively.

Note that in Table 6 we use the same instrument to study the effects of trade protection on different outcome variables. As explained by Heath et al. (2019), this may lead researchers to over-reject the null (an increase in the number of Type I errors), resulting in biased causal inferences. To account for this, we use the procedure developed by Romano and Wolf (2005, 2016) that controls for the family-wise error rate (probability of making at least one false rejection among the hypotheses) and the dependence across tests. By considering the five outcome variables jointly, and applying the Romano-Wolf correction with 1,000 bootstrapped replications, we find that even though the $p$-values of our benchmark coefficients rise slightly, the coefficients in columns 1,3,4, and 5 of Table 6 are significant at the $5 \%$ level.

\subsection{Mechanisms}

In Tables 4-6 above, we have shown that AD duties have negative effects along supply chains, reducing their growth rate of employment, wages, sales, and investment in downstream industries. In what follows, we provide evidence for the mechanism behind these results: higher tariffs decrease imports of targeted products and raise the cost of production in downstream industries. 


\section{The Impact of Tariffs on Imports}

We first examine the impact of AD on US imports of targeted products by estimating the following 2SLS regression: ${ }^{61}$

$$
\Delta \text { Imports from } \text { China }_{j, T}=\beta_{0}+\beta_{1} \Delta \text { Tariff }_{j, T}+\delta_{j}+\delta_{T}+\varepsilon_{j, T} .
$$

The dependent variable is the annualized log change in US imports from China in SIC4 industry $j$ during term $T$. If $\mathrm{AD}$ protection is effective in reducing imports from China, the estimated $\beta_{1}$ coefficient should be negative and significant.

\section{Table 7}

The impact of tariffs on imports and prices

\begin{tabular}{|c|c|c|c|c|}
\hline & \multicolumn{2}{|c|}{ Imports } & \multicolumn{2}{|c|}{ Prices } \\
\hline & $\begin{array}{l}\text { China } \\
\text { (1) }\end{array}$ & $\begin{array}{c}\text { top } 50 \text { exporters } \\
(2)\end{array}$ & $\begin{array}{c}\text { Domestic goods } \\
\text { (3) }\end{array}$ & $\begin{array}{c}\text { All inputs } \\
\text { (4) }\end{array}$ \\
\hline$\Delta$ Tariff $_{j, T}$ & $\begin{array}{c}-0.134^{* * *} \\
(0.048)\end{array}$ & $\begin{array}{c}0.024 \\
(0.026)\end{array}$ & $\begin{array}{c}0.056^{* * *} \\
(0.015)\end{array}$ & \\
\hline$\Delta$ Tariff $_{j, T} \times$ China $_{c}$ & & $\begin{array}{c}-0.213^{* * *} \\
(0.079)\end{array}$ & & \\
\hline$\Delta$ Input Tariff $_{j, T}$ & & & & $\begin{array}{c}0.059^{* * *} \\
(0.019)\end{array}$ \\
\hline SIC4 FE & Yes & No & Yes & Yes \\
\hline Term FE & Yes & No & Yes & Yes \\
\hline SIC $4 \times$ Country FE & No & Yes & No & No \\
\hline Term $\times$ Country FE & No & Yes & No & No \\
\hline Observations & 2,687 & 100,696 & 2,058 & 2,320 \\
\hline KP F-statistic & 16.2 & 8.11 & 16.6 & 170.9 \\
\hline
\end{tabular}

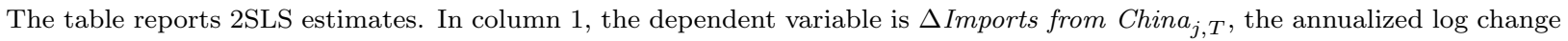
in US imports from China in SIC4 industry $i$ during term $T$, while in column 2 is $\Delta$ Imports $_{j, c, T}$, the annualized log change

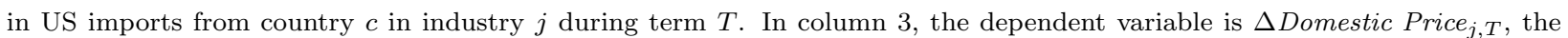
annualized log change in the price of domestic goods in SIC4 industry $j$ during term $T$, constructed using US PPI data, while in column 4 is $\Delta$ Input $_{\text {Price }_{j, T}}$, the annualized log change in the price of material inputs used in SIC4 industry $j$ during term $T$ constructed from the NBER-CES database. $\Delta$ Tariff $_{j, T}$ is the change in the average input tariff of industry $j$ applied by the

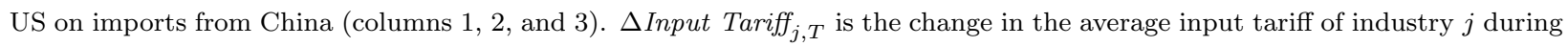
term T. In columns 1 and 2, and the sample covers all tradable industries in 1991-2016; in column 3, the sample covers all industries in 1988-2011; in column 4, the sample covers all manufacturing industries in 1991-2011. Observations are weighted by 1988 employment. Standard errors are clustered at the SIC3 industry level; ***, **, and * denote significance at the $1 \%$, $5 \%$, and $10 \%$ levels respectively.

${ }^{61}$ Notice that this regression is based on tradable goods only. For the first presidential term in our sample period (1988-1992 term), we use data for 1991-1992 due to unavailability of import data prior to 1991. 
The results of estimating (13) are reported in column 1 of Table 7 . The coefficient of $\Delta$ Tariff $_{j, T}$ is negative and significant at the $1 \%$ level, and indicates that a one percentage point increase in predicted $\mathrm{AD}$ duties leads to a 0.13 percentage point decrease in the annual growth rate of imports.

As mentioned in Section 2, several studies have shown that AD duties targeting one country can lead to an increase in imports from non-targeted countries (e.g. Prusa, 1997; Konings et al., 2001). In column 2 of Table 7, examine whether AD protection against China led not only to a decrease in imports from China (trade destruction), but also to an increase in US imports from non-targeted countries (trade diversion). To this purpose, we estimate the following:

$$
\Delta \text { Imports }_{j, c, T}=\beta_{0}+\beta_{1} \Delta \text { Tariff }_{j, T}+\beta_{2} \Delta \text { Tariff } \times \text { China }_{c}+\delta_{j, c}+\delta_{c, T}+\varepsilon_{j, c, T},
$$

where $\delta_{j, c}$ and $\delta_{c, T}$ denote industry-country and country-term fixed effects. The sample includes the top-50 largest exporters to the United States, ranked by their average share in US imports during 1988-2016. We find no evidence that AD protection against China increased US imports from other countries (the estimated $\beta_{1}$ coefficient is insignificant). The trade destruction effect of $\mathrm{AD}$ protection on China is captured by the sum of the coefficients $\beta_{1}$ and $\beta_{2}$, which is negative and significant at the $1 \%$ level. ${ }^{62}$

\section{The Impact of Tariffs on Prices}

In this subsection, we run 2SLS regressions similar to equation (10), examining the impact of AD duties on the prices of protected goods and on input prices. The results are reported in columns 3 and 4 of Table 7 .

In column 3, we examine the effects of $\mathrm{AD}$ duties against China on domestic prices using PPI data. The coefficient of $\Delta$ Tariff $_{j, T}$ is positive and significant, indicating that AD duties raise the price charged by domestic import-competing producers. In terms of magnitude, our estimates imply that a one standard deviation (0.057) increase in AD duties increases the annual growth rate of domestic prices by 0.6 percentage points, which explains $28.4 \%$ of the standard deviation in the average growth rate of domestic prices during 1988-2016.

In column 4, we examine the effects of tariffs on the input prices faced by downstream industry $j$ proxied by the variable Input Price $e_{j, T}$ constructed from the NBER-CES database. The coefficient of $\Delta$ Input Tariff $_{j, T}$ is positive and significant, indicating that higher input

\footnotetext{
${ }^{62}$ In this specification with two endogenous regressors, the KP statistic is 8.11 , which is still above the critical value for the KP statistic based on a $10 \%$ maximal IV size (7.0).
} 
tariffs raise input costs. In terms of magnitude, one standard deviation (0.029) increase in the average input tariff increases the annual growth rate of input prices by 0.2 percentage points, which explains $7.1 \%$ of the standard deviation of the average growth rate of input prices during our sample period. ${ }^{63}$

Overall, the results of Table 7 indicate that AD duties increase the price of the protected products, increasing production costs for firms in downstream industries, independently of whether they source the protected inputs from foreign or domestic suppliers. ${ }^{64}$

\subsection{The Effects on Protected Industries}

Our baseline results (Table 4 and all the corresponding robustness checks) show that AD duties reduce employment growth in downstream industries. Is there any evidence that these measures foster employment growth in the protected industries? To answer this question, we estimate the following 2SLS specification:

$$
\Delta L_{j, T}=\beta_{0}+\beta_{1} \Delta \text { Tariff }_{j, T}+\delta_{j}+\delta_{T}+\varepsilon_{j, T}
$$

where $\Delta L_{j, T}$ is the annualized log change in employment in SIC4 industry $j$ during term $T$, and $\Delta$ Tariff $_{j, T}$ is the change in the AD duty on imports from China in industry $j$ during term $T$. In this regression, the sample is restricted to tradable industries only.

The results of estimating (15) are reported in column 1 of Table A-17 in the Appendix. We find no evidence of employment gains in protected industries: the coefficient of $\Delta \operatorname{Tariff}_{j, T}$ is not significant. This may partly be due to measurement error, due to the fact that a SIC4 industry can include both producers of protected HS6, as well as producers that use those HS6 as inputs. Moreover, given the importance of the diagonal of the I-O matrix at the SIC4 level, the coefficient of the variable $\Delta$ Tariff $_{j, T}$ may confound the effect of final good protection and input protection.

We thus find no evidence that $\mathrm{AD}$ duties stimulate employment growth in protected industries, notwithstanding the fact that these duties do reduce import competition and increase domestic prices (see Table 7). Using data from the NBER-CES Manufacturing Industry Database, we can also study the effects on other outcome variables. The results

\footnotetext{
${ }^{63}$ Previous studies (e.g. Blonigen and Park, 2004; Blonigen and Haynes, 2002 and 2010; Lu et al., 2013) show that AD duties also increase the price of imported goods. We have examined the effects of AD protection on the prices of goods imported from China, using data from Comtrade on unit values of US imports. We find a positive but insignificant coefficient, possibly due to missing data on imported quantities (we lose around six hundreds of observations when using this variable).

${ }^{64}$ Consistent with this reasoning, De Loecker et al. (2016) find substantial declines in domestic good prices due to trade liberalization in India.
} 
reported in columns 2-6 of Table A-17 show that AD duties have no significant effect on blue/collar jobs, wages, and sales in protected industries, but have a positive impact on investment.

\section{Conclusion}

The US-China trade war triggered by President Trump's 2018 tariffs has stimulated a flourishing literature on the costs of protection. In this paper, we have shown that, well before President Trump took office, the US had been applying increasingly high tariffs on imports from China, in the form of $\mathrm{AD}$ duties. Combining detailed information on these measures with US input-output data, we have examined the effects of protection along supply chains.

Our analysis emphasizes the importance of addressing the endogeneity of trade policy for identifying the impact of tariffs along supply chains. We show that, if we ignore these concerns and estimate simple OLS regressions, we find no systematic evidence that higher tariffs in upstream industries affect downstream industries. If instead we instrument for AD tariffs - exploiting exogenous variation in the political importance of different industries and in their historical experience at dealing with the complex AD proceedings - we find that they lead to a significant decrease in employment, wages, sales, and investment in downstream industries.

We also provide evidence of the mechanisms behind the negative effects of tariffs along supply chains: AD duties against China decrease US imports of targeted products and raise the prices charged by both foreign and domestic producers of these products, increasing production costs for firms in downstream industries.

Our baseline estimates imply that, between the start of the presidency of George H. W. Bush in 1988 and the end of Barack Obama's second term in 2016, around 1.8 million US jobs were lost in downstream industries due to AD protection. This figure is sizable, as it is about $4.8 \%$ of the 38 million jobs the US economy added during 1988-2016. We find no evidence that AD duties saved jobs in the protected industries. When extending the analysis to measures introduced under President Trump, we find that around 500,000 US jobs were lost across all industries during the first two years of his term.

Our results resonate with concerns often heard in the media about the costs of protection along supply chains. For example, in a joint statement in March 2018, the National Tooling and Machining Association and the Precision Metalforming Association protested against President Trump's tariffs on steel, which they argued "will cost manufacturing jobs across 
the country," emphasizing that 6.5 million workers are employed in steel-and aluminumusing industries in the US, compared to only 80,000 employed in the steel industry. ${ }^{65}$ Our study supports these concerns, showing that tariffs may not be effective at saving jobs in the protected industries, and destroy many jobs in the rest of the economy.

Previous studies provide an economic rationale for allowing flexible protectionist measures such as AD duties in trade agreements: the ability to protect industries in the face of import surges can act as a "safety valve," allowing countries to sustain trade policy cooperation (Bagwell and Staiger, 1990). Our paper emphasizes the political economy motives for flexible trade barriers (in the spirit of Bagwell and Staiger, 2005): being able to protect certain industries can help politicians to gain votes. These motives are particularly important in the United States, where swing-state politics creates incentives to favor key industries in battleground states.

In this respect, our paper contributes to the ongoing debate about the use of protectionist measures in the multilateral trading system and the sustainability of the WTO dispute settlement process. For years, the WTO had a reliable mechanism to resolve disputes between its members. Since December 2019, this mechanism is deadlocked, due to the refusal of the Trump administration to appoint new members to the Appellate Body, which is in charge of appeals. This follows strong criticism of the Appellate Body by the United States, for overreaching in its handling of trade disputes, in particular those related to US AD duties. In fact, in virtually all disputes concerning US AD duties, the Appellate Body ruled against the United States because of the methodology used to determine dumping margins. ${ }^{66}$ In a report published in February 2020, the Trump administration argued that the Appellate Body has "diminished U.S. rights by failing to comply with WTO rules, addressing issues it has no authority to address, taking actions it has no authority to take, and interpreting WTO agreements in ways not envisioned by the WTO Members who entered into those agreements" (USTR, 2020). As pointed out by Stephen Vaughn, former General Counsel of the United States Trade Representative, AD protection in United States is "very sensitive here in a way that they may not be in other countries. The Appellate Body obviously hasn't been sensitive to any of that, and they've simply trampled those laws every chance they've gotten." 67

\footnotetext{
65 "Thousands of jobs at risk over tariffs, US manufacturers warn" (Financial Times, March 1, 2018).

${ }^{66}$ The methodology is question is "zeroing," which makes it more likely that dumping will be found and inflates the size of the remedying tariff. Between 2002 and 2017, America faced nearly 20 disputes over its use of zeroing in dozens of antidumping cases (see Bown, 2020).

${ }^{67}$ See Trade Talks Episode 111, "Trade Policy Under Trump."
} 


\section{References}

Acemoglu, D., D. H. Autor, D. Dorn, G. H. Hanson, and B. Price (2016). "Import Competition and the Great US Employment Sag of the 2000s," Journal of Labor Economics 34, 141-198.

Acemoglu, D., S. Johnson, and T. Mitton (2009). "Determinants of Vertical Integration: Financial Development and Contracting Costs," Journal of Finance 63, 1251-1290.

Alfaro, L., P. Antràs, D. Chor, and P. Conconi (2019). "Internalizing Global Value Chains: A Firm-Level Analysis," Journal of Political Economy 127, 508-559.

Alfaro, L., P. Conconi, H. Fadinger, and A. F. Newman (2016). "Do Prices Determine Vertical Integration?" Review of Economic Studies 83, 855-888.

Amiti, M., and J. Konings (2007). "Trade Liberalization, Intermediate Inputs, and Productivity: Evidence from Indonesia," American Economic Review 97, 1611-1638.

Amiti, M., S. J. Redding, and D. E. Weinstein (2019). "The Impact of the 2018 Trade War on U.S. Prices and Welfare," Journal of Economic Perspectives 33, 187-210.

Angrist, J. D., and J. S. Pischke (2009). Mostly Harmless Econometrics: An Empiricist's Companion. Princeton University Press.

Antràs, P. (2020). "Conceptual Aspects of Global Value Chains," forthcoming World Bank Economic Review.

Antràs, P., D. Chor, T. Fally, and R. Hillberry (2012). "Measuring the Upstreamness of Production and Trade Flows," American Economic Review Papers \& Proceedings 102, $412-416$.

Antràs, P., T. Fort, and F. Tintelnot (2017). "The Margins of Global Sourcing: Theory and Evidence from US," American Economic Review 107, 2514-2564.

Aquilante, T. (2018). "Undeflected Pressure? The Protectionist Effect of Political Partisanship on US Antidumping Policy," European Journal of Political Economy 55, 455-470.

Autor, D. H., D. Dorn, and G. H. Hanson (2013). "The China Syndrome: Local Labor Market Effects of Import Competition in the United States," American Economic Review 103, 2121-2168.

Autor, D. H., D. Dorn, and G. H. Hanson (2019). "When Work Disappears: Manufacturing Decline and the Falling Marriage-Market Value of Young Men," American Economic Review: Insights 1, 161-178.

Autor, D. H., D. Dorn, G. H. Hanson, and K. Majlesi (2020a). "Importing Political Polarization? The Electoral Consequences of Rising Trade Exposure," American Economic Review 110, 3139-3183.

Autor, D. H., D. Dorn, G. H. Hanson, G. Pisano, and P. Shu (2020b). "Foreign Competition and Domestic Innovation: Evidence from U.S. Patents," American Economic Review: Insights 2, 357-374. 
Bagwell, K., and R. W. Staiger (1990). "A Theory of Managed Trade," American Economic Review 80, 779-795.

Bagwell, K., and R. W. Staiger (2005). "Enforcement, Private Political Pressure and the GATT/WTO Escape Clause," The Journal of Legal Studies 34, 471-513.

Barattieri, A., and M. Cacciatore (2020). "Self-Harming Trade Policy? Protectionism and Production Networks," NBER Working Paper No. 27630.

Bergstrom, T., L. Blume, and H. Varian (1986). "On the Private Provision of Public Goods," Journal of Public Economics 29, 25-49.

Besedes, T., and T. J. Prusa (2017). "The Hazardous Effect of Antidumping," Economic Inquiry 55, 9-30.

Blanchard, E. J., C. P. Bown, and R. C. Johnson (2016). "Global Supply Chains and Trade Policy," NBER Working Paper No. 21883.

Blaum, J., C. Lelarge, and M. Peters (2018). "The Gains from Input Trade with Heterogeneous Importers," American Economic Journal: Macroeconomics 10, 77-127.

Blonigen, B. A. (2006). "Working the System: Firm Learning and the Antidumping Process," European Journal of Political Economy 22, 715-731.

Blonigen, B. A., and C. P. Bown (2003). "Antidumping and Retaliation Threats," Journal of International Economics 60, 249-273.

Blonigen, B. A., and S. E. Haynes (2002). "Antidumping Investigations and the Passthrough of Antidumping Duties and Exchange Rates," American Economic Review 92, 1044-1061.

Blonigen, B. A., and S. E. Haynes (2010). "Antidumping Investigations and the PassThrough of Antidumping Duties and Exchange Rates: Reply," American Economic Review 100, 1283-1284.

Blonigen, B. A., and J. H. Park (2004). "Dynamic Pricing in the Presence of Antidumping Policy: Theory and Evidence," American Economic Review 94, 134-154.

Blonigen, B. A., and T. J. Prusa (2016). "Dumping and Antidumping Duties," in K. Bagwell, and R. W. Staiger (eds), Handbook of Commercial Policy Volume 1B, 107159. Elsevier.

Bombardini, M., and F. Trebbi (2012). "Competition and Political Organization: Together or Alone in Lobbying for Trade Policy?" Journal of International Economics 87, 18-26.

Bown, C. P. (2014). Temporary Trade Barriers Database.

Bown, C. P. (2018). "Trade Policy Toward Supply Chains After the Great Recession," IMF Economic Review 66, 602-616.

Bown, C. P. (2019). "US Special Protection in Historical Perspective: 1974-2018," Working paper 20/4, Peterson Institute for International Economics. 
Bown, C. P. (2020). "Why Trump Shot the Sheriffs: The End of WTO Dispute Settlement 1.0," Working paper 19/7, Peterson Institute for International Economics.

Bown, C. P., and M. A. Crowley (2007). "Trade Deflection and Trade Depression," Journal of International Economics 72, 176-201.

Bown, C. P., and M. A. Crowley (2013). "Self-Enforcing Trade Agreements: Evidence from Time-Varying Trade Policy," American Economic Review 103, 1071-1090.

Bown, C. P., A. Erbahar, and M. Zanardi (2020). "Global Value Chains and the Removal of Trade Protection," CEPR Discussion Paper 14451.

Cavallo, A., G. Gopinath, B. Neiman, and J. Tang (2019). "Tariff Passthrough at the Border and at the Store: Evidence from US Trade Policy," forthcoming American Economic Review: Insights.

Conconi, P., D. DeRemer, G. Kirchsteiger, L. Trimarchi, and M. Zanardi (2017). "Suspiciously Timed Trade Disputes," Journal of International Economics 105, 57-76.

Conconi, P., M. García-Santana, L. Puccio, and R. Venturini (2018). "From Final Goods to Inputs: The Protectionist Effect of Rules of Origin," American Economic Review 108, 2335-2365.

Debaere, P. M. (2009). "Fishy Issues: The U.S. Shrimp Antidumping Case," Darden Case No. UVA-G-0600.

De Loecker, J., P. Goldberg, A. Khandelwal, and N. Pavcnik (2016). "Prices, Markups and Trade Reform," Econometrica 84, 445-510.

Ellison, G., and E. L. Glaeser (1997). "Geographic Concentration in U.S. Manufacturing Industries: A Dartboard Approach," Journal of Political Economy 105, 889-927.

Erbahar, A., and Y. Zi (2017). "Cascading Trade Protection: Evidence from the US," Journal of International Economics 108, 274-299.

Fajgelbaum, P. D., P. K. Goldberg, P. J. Kennedy, and A. K. Khandelwal (2020). "The Return to Protectionism," Quarterly Journal of Economics 135, 1-55.

Feenstra, R. C. (1996). "US Imports, 1972-1994: Data and Concordances," NBER Working Paper No. 5515.

Feinberg, R. M., and K. M. Reynolds (2006). "The Spread of Antidumping Regimes and the Role of Retaliation in Filings," Southern Economic Journal 72, 877-890.

Feinberg, R. M., and K. M. Reynolds (2008). "Friendly Fire? The Impact of US Antidumping Enforcement on US Exporters," Review of World Economics/Weltwirtschaftliches Archiv 144, 366-378.

Finger, J. M., Blonigen, B. A., and Flynn, J. E. (1982). "The Political Economy of Administered Protection," American Economic Review 72, 452-466. 
Flaaen, A., A. Hortaçsu, and F. Tintelnot (2020). "The Production Relocation and Price Effects of U.S. Trade Policy: The Case of Washing Machines," American Economic Review 110(7), 2103-27.

Flaaen, A., and J. Pierce (2019). "Disentangling the Effects of the 2018-2019 Tariffs on a Globally Connected U.S. Manufacturing Sector," FEDS Working Paper 2019-086.

Gawande, K., P. Krishna, and M. Olarreaga (2012). "Lobbying Competition Over Trade Policy," International Economic Review 53, 115-132.

Goldberg, P. K., A. K. Khandelwal, N. Pavcnik, and P. Topalova (2010). "Imported Intermediate Inputs and Domestic Product Growth: Evidence from India," Quarterly Journal of Economics 125, 1727-1767.

Grossman, G. M., and E. Helpman (2020). "When Tariffs Disturb Global Supply Chains," NBER Working Paper 27722.

Halpern, L., M. Koren, and A. Szeidl (2015). "Imported Inputs and Productivity," American Economic Review 105, 3660-3703.

Hansen, W. L., and T. J. Prusa (1997). "The Economics and Politics of Trade Policy: An Empirical Analysis of ITC Decision Making," Review of International Economics 5, 230-245.

Harmon, N., R. Fisman, and E. Kamenica (2019). "Peer Effects in Legislative Voting," American Economic Journal: Applied Economics 11, 156-180.

Heath, D., M. C. Ringgenberg, M. Samadi, and I. M. Werner (2019). "Reusing Natural Experiments," Working Paper Series 2019-21, Ohio State University, Charles A. Dice Center for Research in Financial Economics.

Imbens, G. W., and J. D. Angrist (1994). "Identification and Estimation of Local Average Treatment Effects," Econometrica 62, 467-475.

Irwin, D. A. (2005). "The Rise of US Anti-dumping Activity in Historical Perspective," The World Economy 28, 651-668.

Irwin, D. A. (2017). "Clashing over Commerce: A History of US Trade Policy," Markets and Governments in Economic History, University of Chicago Press.

Johnson, R. C., and G. Noguera (2012). "Accounting for Intermediates: Production Sharing and Trade in Value Added," Journal of International Economics 86, 224-236.

Konings, J., and H. Vandenbussche (2008). "Heterogeneous Responses of Firms to Trade Protection," Journal of International Economics 76, 371-383.

Konings, J., H. Vandenbussche, and L. Springael (2001). "Import Diversion under European Antidumping Policy," Journal of Industry, Competition and Trade 1, 283-299.

Lu, Y., Z. Tao, and Y. Zhang (2013). "How do Exporters Respond to Antidumping Investigations?," Journal of International Economics 9, 290. 
Ma, X., and J. McLaren (2018). "A Swing-State Theorem, with Evidence," NBER Working Paper No. 24425.

Mayda, A., R. Ludema, and P. Mishra (2018). "Information and Legislative Bargaining: The Political Economy of U.S. Tariff Suspensions," Review of Economics and Statistics 100, 303-318.

Moore, M. (1992). "Rules or Politics? An Empirical Analysis of Antidumping Decisions," Economic Inquiry 30, 449-466.

Muûls, M., and D. Petropoulou (2013). "A Swing State Theory of Trade Protection in the Electoral College," Canadian Journal of Economics 46, 705-724.

Olson, M. (1965). "The Logic of Collective Action: Public Goods and the Theory of Groups," Harvard Economic Studies 124. Harvard University Press, Cambridge, Mass.

Pierce, J. R. (2011). "Plant-Level Responses to Antidumping Duties: Evidence from U.S. Manufacturers," Journal of International Economics 85, 222-233.

Pierce, J. R., and P. K. Schott (2016). "The Surprisingly Swift Decline of US Manufacturing Employment," American Economic Review 106, 1632-1662.

Pierce, J. R., and P. K. Schott (2020). "Trade Liberalization and Mortality: Evidence from U.S. Counties," American Economic Review: Insights 2, 47-64.

Prusa, T. J. (1997). "The Trade Effects of U.S. Antidumping Actions," in R. C. Feenstra (ed.), Effects of U.S. Trade Protection and Promotion Policies. Chicago: University of Chicago Press.

Prusa, T. J. (2001). "On the Spread and Impact of Antidumping," Canadian Journal of Economics, 34, 591-611.

Romano, J. P., and M. Wolf (2005). "Stepwise Multiple Testing as Formalized Data Snooping," Econometrica 73 (4), 1237-1282.

Romano, J. P., and M. Wolf (2016). "Efficient Computation of Adjusted p-values for Resampling-based Stepdown Multiple Testing," Statistics and Probability Letters 113, $38-40$.

Trefler, D. (1993). "Trade Liberalization and the Theory of Endogenous Protection: An Econometric Study of U.S. Import Policy," Journal of Political Economy 101, 138-160.

United States Trade Representative (USTR) (2020). "Report on the Appellate Body of the World Trade Organization."

Vandenbussche, H., and C. Viegelahn (2018). "Input Reallocation Within Multi-Product Firms," Journal of International Economics 114, 63-79.

Vandenbussche, H., and M. Zanardi (2010). "The Chilling Trade Effects of Antidumping Proliferation," European Economic Review 54 760-777.

Yi, K-M. (2003). "Can Vertical Specialization Explain the Growth of World Trade?," Journal of Political Economy 111, 52-102. 


\section{Appendix}

\section{A-1 Antidumping and Swing-State Politics}

In this section, we provide novel evidence emphasizing the importance of politics - and in particular swing-state politics - for AD policy in the United States.

The literature on the political economy of US AD policy shows that votes by ITC commissioners reflect the interests of the members of two most powerful committees dealing with trade policy in Congress: the Finance committee in the Senate and the Ways and Means committee in the House. These powerful legislators can put pressure on the ITC through appointment confirmations, budget allocation, oversight hearings, and other channels. Moore (1992) shows that ITC commissioners are more likely to favor AD petitions involving the constituencies of Finance committee members. Hansen and Prusa (1997) show that the ITC is more likely to support petitions filed by industries with representatives in the Ways and Means committee. Aquilante (2018) emphasizes the role of party politics, showing that ITC commissioners appointed by the Democratic (Republican) party are more likely to vote in favor of $\mathrm{AD}$ when the petitioning industry is key (in terms of employment) in the states represented by Democratic (Republican) senators in the Finance committee.

These studies suggest that the composition of the Finance and Ways and Means committees affects AD votes by ITC commissioners. Combining data on membership of congressional committees, ${ }^{68}$ with our variable $\operatorname{Swing}_{s, T}$, we find that congressmen from swing states are overrepresented in these committees: during the eight presidential elections in 1988-2016, swing states accounted for around $21 \%$ of US states on average (see Figure 2). However, around $33 \%$ (36\%) of the new members of the Senate Finance (House Ways and Means) committee in a presidential term represented states classified as swing. This composition bias in the key trade committees may lead ITC decisions to be skewed in favor of key industries in swing states.

Next, using detailed data from Aquilante (2018), we directly examine whether swing-state politics affects ITC commissioners' votes on material injury, focusing on AD cases involving China as a target country. ${ }^{69}$ The ITC is composed of six commissioners who are appointed for nine non-renewable years. ${ }^{70}$ During each year of his or her tenure, each commissioner

\footnotetext{
${ }^{68}$ These data are available from Charles Stewart III and Jonathan Woon, Congressional Committee Assignments, 103rd to 114th Congresses, 1993-2017.

${ }^{69}$ Similar results are obtained looking at $\mathrm{AD}$ cases involving all countries.

${ }^{70}$ In reality, the tenure of ITC commissioners is often shorter and (in a few cases) longer than 9 years (see
} 
casts many votes involving different industries. ${ }^{71}$ To study the role of swing-state politics, we estimate the following:

$$
\text { Vote }_{i, t, c}=\beta_{0}+\beta_{1} \text { Swing }_{i, T}+\delta_{i}+\delta_{t}+\delta_{c}+\varepsilon_{i, t, c}
$$

The dependent variable is $V_{0 t e}, t, c$, a dummy variable which is equal to 1 if ITC commissioner $c$ votes in favor of AD duties against China in year $t$, in a case involving SIC4 industry $i$. The variable Swing $_{i, T}$ defined in equation (5) captures the importance of industry $i$ in states classified as swing during term $T$, and $\delta_{i}, \delta_{t}$ and $\delta_{c}$ denote respectively industry, year, and commissioner fixed effects.

\section{Table A-1}

ITC votes and swing-state politics

\begin{tabular}{lccc}
\hline \hline & $(1)$ & $(2)$ & $(3)$ \\
\hline Swing $_{i, T}$ & $19.391^{* * *}$ & $16.280^{* * *}$ & $0.464^{* * *}$ \\
& $(4.372)$ & $(4.278)$ & $(0.109)$ \\
Swing $_{i, T} \times$ Same Party as President & & \\
& & $7.285^{* * *}$ & \\
Same Party as President & & $(2.394)$ & \\
& & 0.054 & \\
Commissioner FE & & $(0.039)$ & No \\
Year FE & Yes & Yes & Yes \\
SIC4 FE & Yes & Yes & Yes \\
Adjusted $R^{2}$ & Yes & Yes & 0.30 \\
Observations & 0.50 & 0.51 & 113 \\
\hline \hline
\end{tabular}

$\overline{\text { The table reports OLS estimates. In columns } 1 \text { and } 2 \text {, the dependent variable is } \text { Vote }_{i, t, c} \text {, a dummy variable which is equal to }}$ 1 if ITC commissioner $c$ votes in favor of AD duties against China in year $t$, in a case involving SIC4 industry $i$. In column 3 , the dependent variable is Vote Share $i, t$, the share of ITC commissioners voting in favor of AD duties against China in year $t$, in a case involving SIC4 industry $i$. Swing $i_{i, T}$ defined in equation (5) captures the importance of industry $i$ in states classified as swing during term T. Same Party as the President $t_{t, c}$ is a dummy variable equal to 1 if ITC commissioner $c$ belongs to the same party as the incumbent executive in year $t$. The sample covers 1985-2008. Standard errors in parentheses are clustered at the SIC3 industry level. ***, **, and * denote significance at the $1 \%, 5 \%$, and $10 \%$ levels respectively.

The results of estimating (16) are reported in column 1 of Table A-1. The coefficient of Swing $_{i, T}$ is positive and significant at the $1 \%$ level, indicating that ITC commissioners are more likely to vote in favor of $\mathrm{AD}$ protection when the petitioning industry is more Aquilante, 2018).

${ }^{71}$ Focusing on AD cases against China, during 1985-2008 (the sample period covered by Aquilante, 2018), ITC commissioners have cast on average 48 votes ( 8 per year). 
important in swing states. One might expect that granting AD protection to key industries in swing states would boost the electoral chances of the incumbent president's party in the next elections, possibly because voters are motivated by reciprocity, as in Conconi et al. (2017). If this is the case, we might expect ITC commissioners who belong to the same party as the president to be particularly sensitive to the interests of swing states. To verify this, we include in (16) the interaction between Swing $_{i, T}$ and Same Party as the President ${ }_{c, T}$, a dummy variable equal to 1 if ITC commissioner $c$ belongs to the same party as the incumbent executive during term $T$. The results reported in column 2 of Table A-1 show that belonging to the same party as the president increases commissioners' propensity to vote in favor of key industries in swing states.

Previous studies emphasize the importance of peer effects in legislative voting (e.g. Harmon et al., 2019), suggesting that ITC commissioners may be affected by their colleagues when voting on $\mathrm{AD}$. To allow for these interdependences, we examine the role of swing-state politics at a more aggregate level, estimating the effects of $\operatorname{Swing}_{i, T}$ on the share of politicians that vote in favor of $\mathrm{AD}$ :

$$
\text { Vote }_{\text {Share }}, t=\beta_{0}+\beta_{1} \text { Swing }_{i, T}+\delta_{i}+\delta_{t}+\varepsilon_{i, t} \text {. }
$$

The results of this estimation are reported in column 3 of Table A-1. The coefficient of Swing $_{i, T}$ remains positive and significant, confirming that ITC commissioners are more likely to vote in favor of $\mathrm{AD}$ when the petitioning industry is more important in battleground states. 


\section{A-2 Figures}

\section{Figure A-1}

Share of US imports from China covered by AD duties

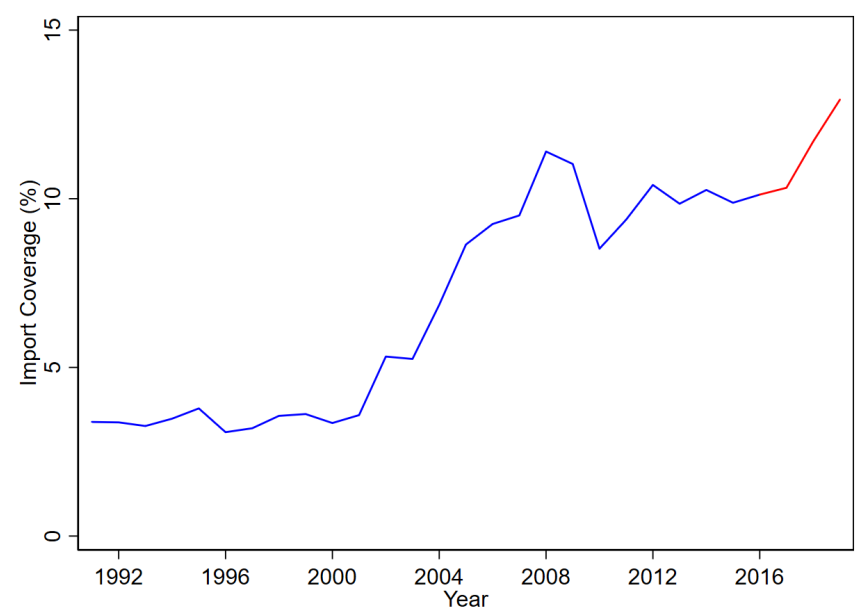

The figure plots the share of US imports from China covered by US antidumping duties in 1991-2016 (in blue) and during Trump's presidency in 2017-2019 (in red). Source: Authors' calculations based on an extended version of the Temporary Trade Barriers Database.

\section{Figure A-2}

Number of US AD duties, countervailing duties, and safeguards against China (1988-2019)

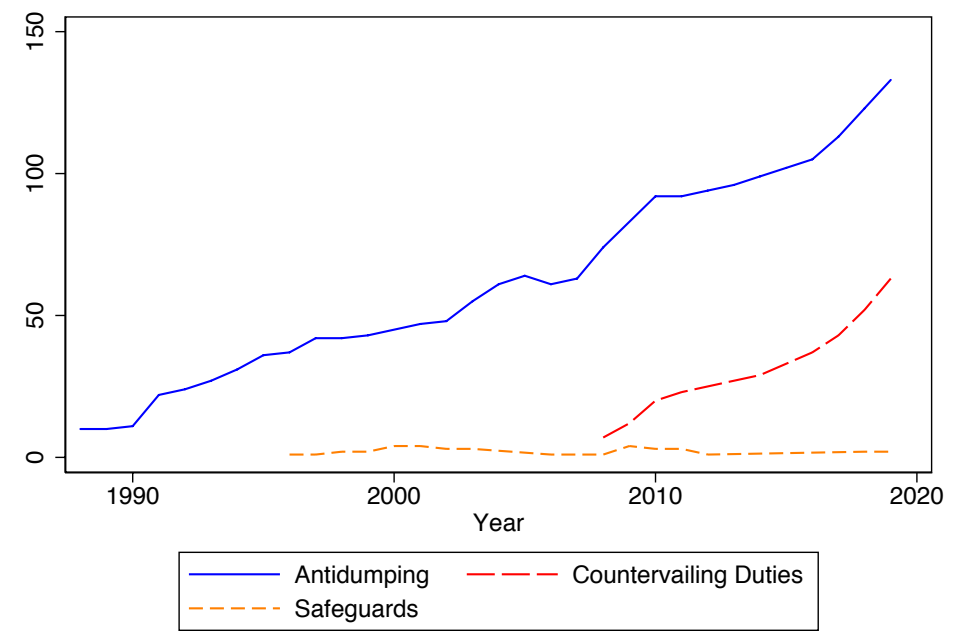

The figure plots the number of AD duties, countervailing duties, and safeguards applied by the US on imports from China. Source: Authors' calculations based on an extended version of the Temporary Trade Barriers Database. 


\section{Figure A-3}

Average IO coefficients of the most important inputs

(a) Top-10

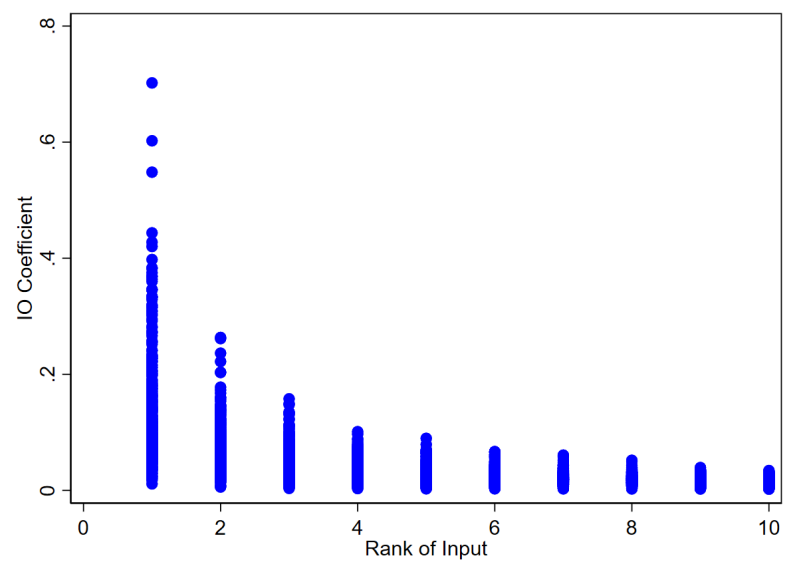

(b) Top-50

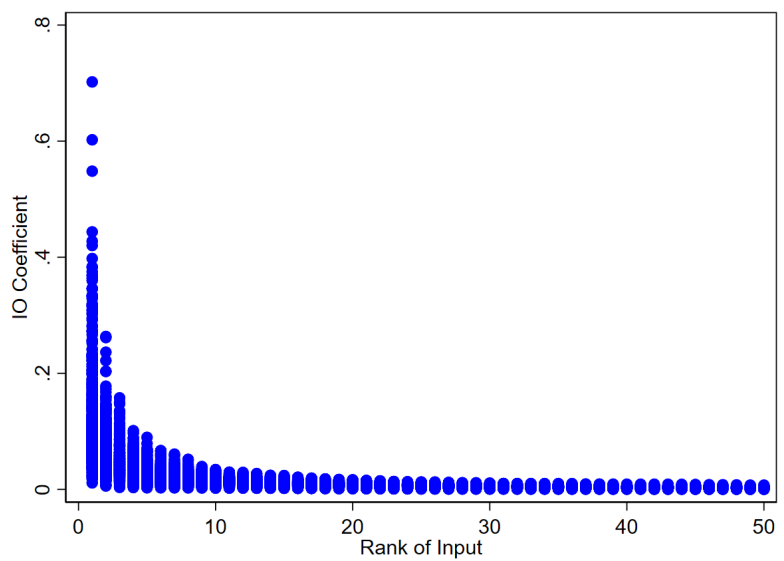

The figures plot the average direct requirement coefficients $\omega_{i, j}$ across all 479 SIC $4 j$ industries, focusing on the top-10 and top-50 most important inputs $i(\neq j)$ for each industry $j$ (i.e. highest $\omega_{i, j}$ ) in panels (a) and (b) respectively.

Figure A-4

IO coefficients

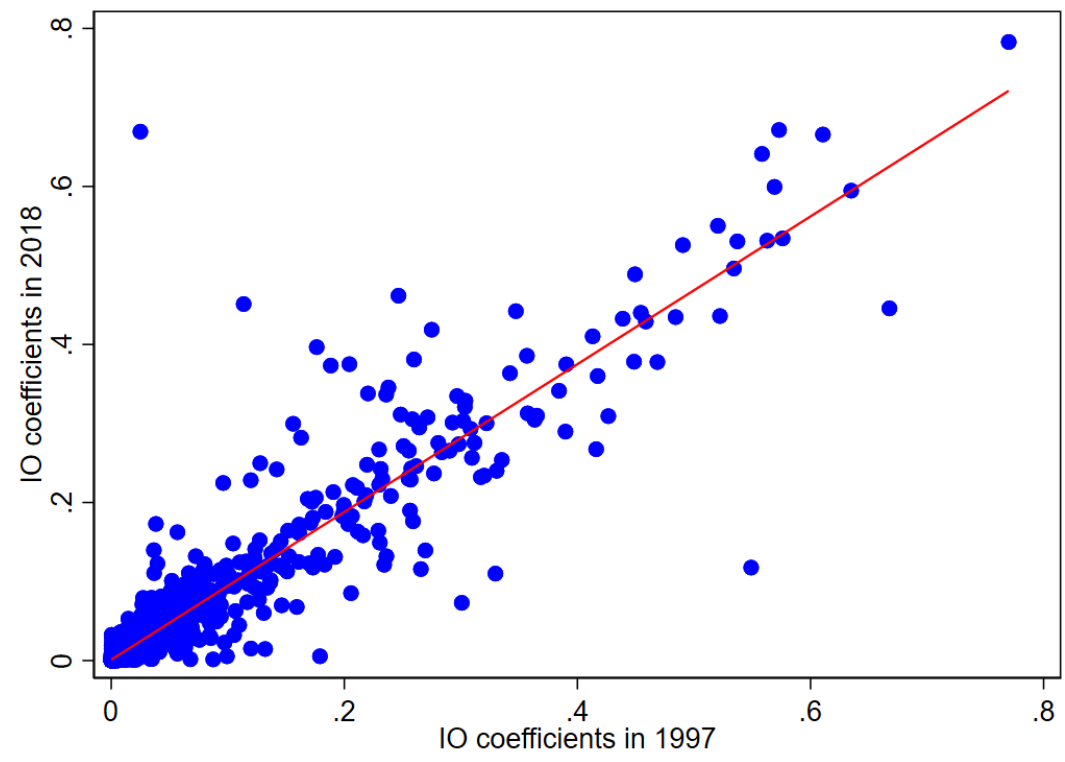

The figure plots direct requirement coefficients from the BEA 1997-2018 tables. Industry classifications are concorded over time and aggregated to 71 industries. 


\section{Figure A-5}

SIC4 employment shares by state

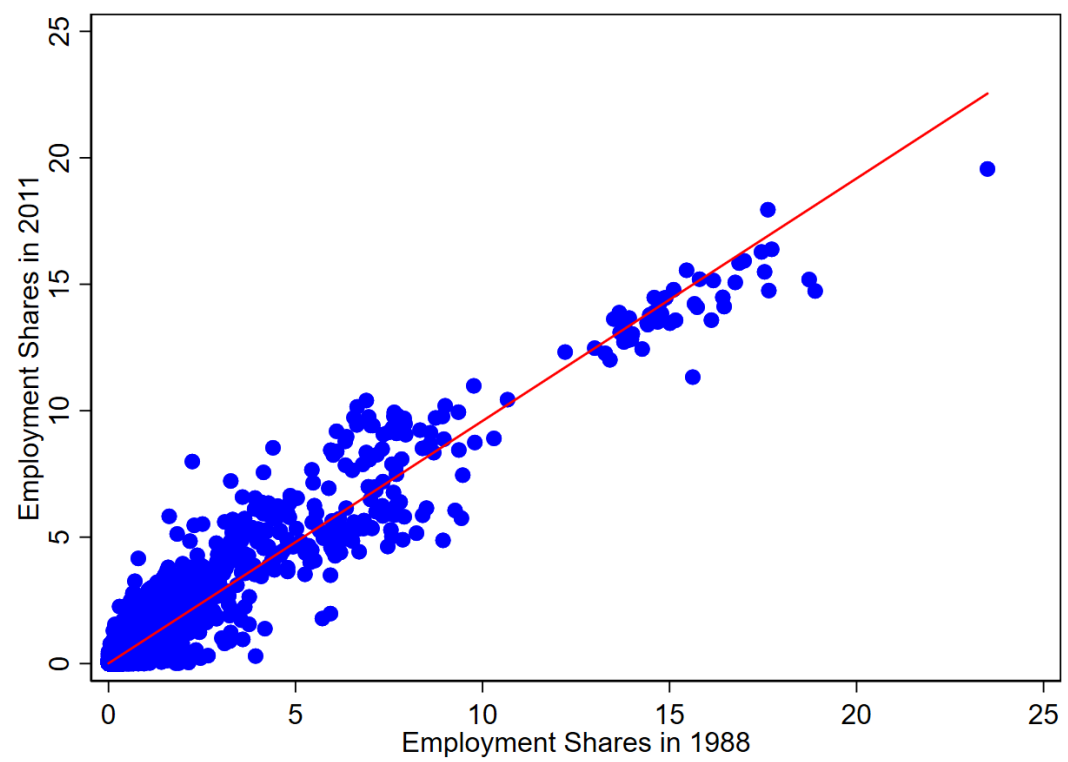

The figure plots state-level industry employment shares in 1988 and 2011, based on data from Acemoglu et al. (2016).

\section{Figure A-6}

Geographical distribution of steel and construction (based on 1988 employment shares)
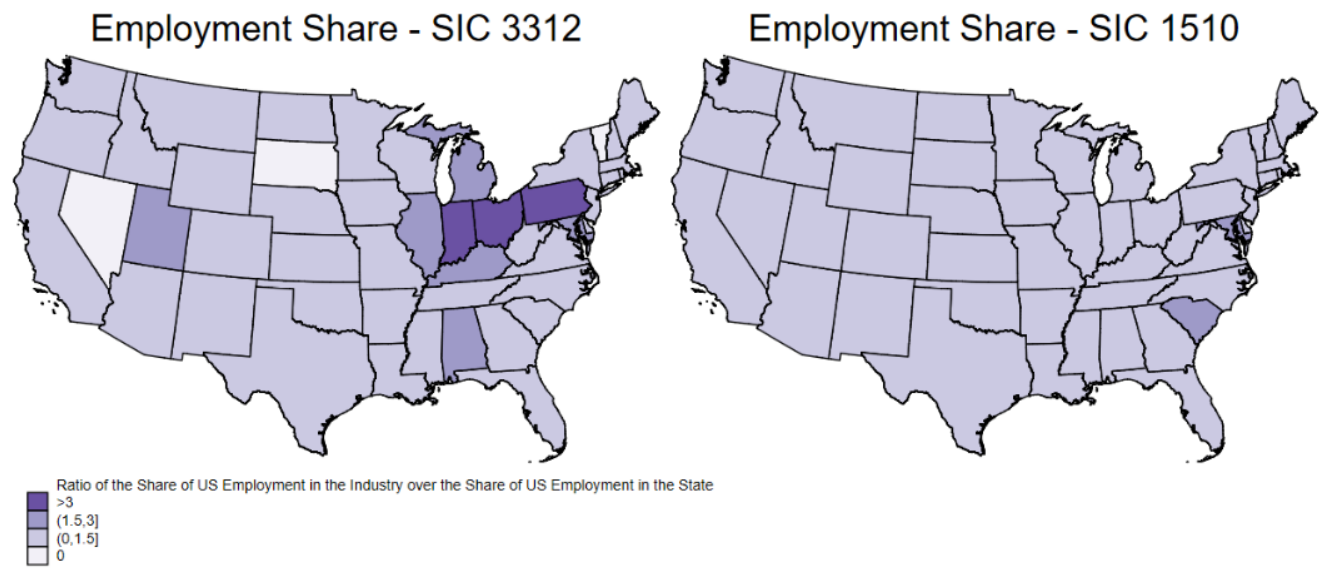

The maps indicate state-level shares of US employment in industries SIC 3312 ("Blast furnaces and steel mills") and SIC 1510 ("Construction") in 1988 over state-level shares of overall US employment in the same year. 


\section{A-3 Descriptive Statistics}

Table A-2

Descriptive statistics on tariffs applied by the United States against China

\begin{tabular}{lcccc}
\hline \hline & & \multicolumn{2}{c}{ (a) AD duties, 1988-2016 } \\
Variable & Mean & Std. Dev. & Min & Max \\
\hline Tariff $_{j, t}$ & 0.15 & 0.53 & 0.00 & 4.30 \\
Average Input Tariff & & 0.15 & 0.00 & 1.07 \\
Tariff on Key Input $_{1, j, t}$ & 0.14 & 0.63 & 0.00 & 3.77
\end{tabular}

(b) MFN tariffs, 1988-2016

\begin{tabular}{lcccc} 
Variable & Mean & Std. Dev. & Min & Max \\
\hline Tariff $_{j, t}$ & 0.05 & 0.21 & 0.00 & 3.50 \\
Average Input Tariff $j, t$ & 0.02 & 0.03 & 0.00 & 0.43 \\
${\text { Tariff on Key } \text { Input }_{1, j, t}}$ & 0.05 & 0.23 & 0.00 & 3.50 \\
\hline
\end{tabular}

(c) AD duties, 2017-2018

\begin{tabular}{lcccc} 
Variable & Mean & Std. Dev. & Min & Max \\
\hline Tariff $_{j, t}$ & 0.36 & 0.81 & 0.00 & 4.93 \\
Average Input Tariff $f_{, t}$ & 0.34 & 0.21 & 0.02 & 1.01 \\
${\text { Tariff on Key } \text { Input }_{1, j, t}}^{\text {An }}$ & 0.88 & 0.88 & 0.00 & 3.73 \\
\hline
\end{tabular}

(d) Section 201, 232, and 301 tariffs, 2018

\begin{tabular}{lcccc} 
Variable & Mean & Std. Dev. & Min & Max \\
\hline Tariff $_{j, t}$ & 0.11 & 0.07 & 0.00 & 0.25 \\
Average Input Tariff & & 0.03 & 0.00 & 0.15 \\
Tariff on Key Input $_{1, j, t}$ & 0.13 & 0.05 & 0.00 & 0.25 \\
\hline \hline
\end{tabular}

The rates reported are ad valorem. The variable $\operatorname{Tariff}_{j, t}$ is constructed for the 405 tradable industries, while the variables Average Input Tariff ${ }_{j, t}$ and Tariff on Key Input $_{1, j, t}$ are constructed for all 479 industries. 
Table A-3

Descriptive statistics on Experience ${ }_{i}$ Swing $_{i, T}$ and $I V_{i, T}$

\begin{tabular}{lcccc}
\hline \hline Variable & Mean & Std. Dev. & Min & Max \\
\hline$I V_{i, T}$ & 0.005 & 0.054 & 0 & 1.497 \\
Experience $_{i}$ & 0.815 & 3.005 & 0 & 57 \\
Swing $_{i, T}$ & 0.002 & 0.004 & 0 & 0.045 \\
\hline \hline
\end{tabular}

The table reports the descriptive statistics of our instrument for AD protection, $I V_{i, T}$, and of its components, Experience ${ }_{i}$ and Swing $_{i, T}$.

Table A-4

Top-10 Sectors by Experience ${ }_{i}$ and Swing $_{i, T}$

Experience $_{i}$

\begin{tabular}{llc}
\hline \hline Sector & Description & Tariff $f_{i, t}(\%)$ \\
\hline 3312 & Blast furnaces and steel mills & 81.61 \\
3714 & Motor vehicle parts and accessories & 142.9 \\
3496 & Misc. fabricated wire products & 114.7 \\
2869 & Industrial organic chemicals, n.e.c. & 125.1 \\
2819 & Industrial inorganic chemicals, n.e.c. & 68.95 \\
2241 & Narrow fabric mills & 59.78 \\
3537 & Industrial trucks and tractors & 0 \\
2399 & Fabricated textile products, n.e.c. & 59.78 \\
3991 & Brooms and brushes & 189.6 \\
3069 & Fabricated rubber products, n.e.c. & 0 \\
& \multicolumn{1}{c}{ Swing $g_{i, T}$} & \\
\hline \hline
\end{tabular}

\begin{tabular}{llc}
\hline \hline Sector & Description & Tariff $f_{i, t}(\%)$ \\
\hline 2752 & Commercial printing, lithographic & 35.78 \\
3089 & Plastics products, n.e.c. & 1.461 \\
2599 & Furniture and fixtures, n.e.c. & 71.06 \\
3714 & Motor vehicle parts and accessories & 142.9 \\
2711 & Newspapers & 0 \\
3711 & Motor vehicles and car bodies & 0 \\
3312 & Blast furnaces and steel mills & 81.61 \\
3812 & Search and navigation equipment & 0 \\
3499 & Fabricated metal products, n.e.c. & 36.33 \\
3599 & Industrial machinery, n.e.c. & 106.6 \\
\hline \hline
\end{tabular}

The table lists the top-10 SIC4 sectors with the highest value of Experience $_{i}$ defined between 1980-1987 (top panel) and the highest average value of Swing $_{i, T}$ during 1988-2016 (bottom panel), with the corresponding average AD duty. 
Table A-5

Top-10 protected sectors

\begin{tabular}{llc}
\hline \hline SIC4 & SIC4 description & Average tariff \\
\hline 0710 & Agriculture & $245.5 \%$ \\
2033 & Canned fruits and vegetables & $243.5 \%$ \\
2037 & Frozen fruits and vegetables & $237.1 \%$ \\
2035 & Pickles, sauces, and salad dressings & $234.9 \%$ \\
3792 & Travel trailers and campers & $172.0 \%$ \\
3399 & Primary metal products, n.e.c. & $134.6 \%$ \\
3339 & Primary nonferrous metals, n.e.c. & $125.9 \%$ \\
2869 & Industrial organic chemicals, n.e.c. & $125.1 \%$ \\
0900 & Fishing, hunting, and trapping & $120.7 \%$ \\
3494 & Valves and pipe fittings, n.e.c. & $117.7 \%$ \\
\hline \hline
\end{tabular}

Column 1 shows the top-10 SIC4 protected sectors with the highest average tariffs, based on US AD duties against China, and column 2 indicates the SIC4 description. Column 3 shows the average tariff over 1988-2016.

Table A-6

Top 10 key inputs

\begin{tabular}{llcc}
\hline \hline SIC4 & Input industry & $\begin{array}{c}\text { Share of } \\
\text { downstream industries }\end{array}$ & $\begin{array}{c}\text { Average cost share } \\
\text { of key input }\end{array}$ \\
\hline 3312 & Blast furnaces and steel mills & 0.17 & 0.11 \\
1221 & Coal and petroleum & 0.10 & 0.09 \\
2221 & Broadwoven fabric mills, manmade & 0.06 & 0.10 \\
2752 & Commercial printing, lithographic & 0.06 & 0.04 \\
2621 & Paper mills & 0.05 & 0.20 \\
3679 & Electronic components, n.e.c. & 0.05 & 0.06 \\
2869 & Industrial organic chemicals, n.e.c. & 0.04 & 0.11 \\
2821 & Plastics materials and resins & 0.03 & 0.12 \\
2911 & Petroleum refining & 0.03 & 0.10 \\
3674 & Semiconductors and related devices & 0.03 & 0.04 \\
\hline \hline
\end{tabular}

The table list the 10 most important tradable input industries $i$. Column 1 reports the share of industries $j$ for which input $i$ is the key input (i.e. highest cost share $\omega_{i, j}$ ). Column 2 reports the average cost shares of industry $i$ (across all industries $j$ for which $i$ is the key input). 
Table A-7

Top-10 affected sectors, by average input tariff

\begin{tabular}{|c|c|c|c|c|c|}
\hline SIC4 & SIC4 description & Average input tariff & Average tariff on key input & Key input SIC4 & Key input description \\
\hline 0800 & Forestry & $61.78 \%$ & $245.53 \%$ & 0710 & Agriculture \\
\hline 3449 & Miscellaneous metal work & $50.17 \%$ & $81.61 \%$ & 3312 & Blast furnaces and steel mills \\
\hline 2653 & Corrugated and solid fiber boxes & $44.30 \%$ & $76.93 \%$ & 2621 & Paper mills \\
\hline 3412 & Metal barrels, drums, and pails & $43.78 \%$ & $81.61 \%$ & 3312 & Blast furnaces and steel mills \\
\hline 3448 & Prefabricated metal buildings & $43.12 \%$ & $81.61 \%$ & 3312 & Blast furnaces and steel mills \\
\hline 2821 & Plastics materials and resins & $42.24 \%$ & $125.09 \%$ & 2869 & Industrial organic chemicals, n.e.c. \\
\hline 2674 & Bags: uncoated paper and multiwall & $40.81 \%$ & $76.93 \%$ & 2621 & Paper mills \\
\hline 3084 & Plastics pipe & $40.62 \%$ & $53.04 \%$ & 2821 & Plastics materials and resins \\
\hline 2655 & Fiber cans, drums and similar products & $40.04 \%$ & $76.93 \%$ & 2621 & Paper mills \\
\hline 3465 & Automotive stampings & $39.18 \%$ & $81.61 \%$ & 3312 & Blast furnaces and steel mills \\
\hline
\end{tabular}

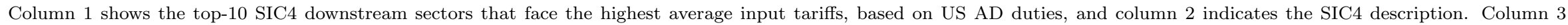

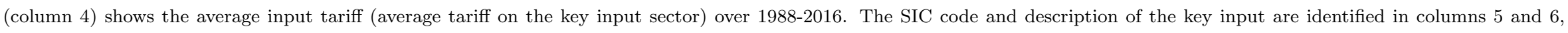
respectively. 


\title{
A-4 Additional Results and Robustness Checks
}

\author{
Table A-8
}

First-stage and reduced-form results for Table 4

\begin{tabular}{|c|c|c|c|c|}
\hline & \multicolumn{4}{|c|}{ First-stage results } \\
\hline & \multicolumn{2}{|c|}{ All sectors } & \multicolumn{2}{|c|}{ Manufacturing sectors only } \\
\hline & $\begin{array}{l}\text { Average input tariff } \\
\text { (1) }\end{array}$ & $\begin{array}{c}\text { Tariff on key input } \\
(2)\end{array}$ & $\begin{array}{l}\text { Average input tariff } \\
(3)\end{array}$ & $\begin{array}{c}\text { Tariff on key input } \\
\text { (4) }\end{array}$ \\
\hline \multirow{2}{*}{$\Delta I V_{j, T}$} & $0.001^{* * *}$ & $0.682^{* * *}$ & $0.001^{* * *}$ & $0.714^{* * *}$ \\
\hline & $(0.000)$ & $(0.019)$ & $(0.000)$ & $(0.027)$ \\
\hline SIC4 FE & Yes & Yes & Yes & Yes \\
\hline Year FE & Yes & Yes & Yes & Yes \\
\hline Observations & 3,351 & 3,351 & 2,742 & 2,742 \\
\hline \multirow[t]{4}{*}{ Adjusted $R^{2}$} & 0.29 & 0.31 & 0.29 & 0.28 \\
\hline & \multicolumn{4}{|c|}{ Reduced-form results } \\
\hline & \multicolumn{2}{|c|}{ All sectors } & \multicolumn{2}{|c|}{ Manufacturing sectors only } \\
\hline & Average input tariff & Tariff on key input & Average input tariff & Tariff on key input \\
\hline \multirow{3}{*}{$\Delta I V_{j, T}$} & $(5)$ & $(6)$ & $(7)$ & $(8)$ \\
\hline & $-0.000^{* * *}$ & $-0.029^{* * *}$ & $-0.000^{* * *}$ & $-0.014^{* * *}$ \\
\hline & $(0.000)$ & $(0.006)$ & $(0.000)$ & $(0.004)$ \\
\hline SIC4 FE & Yes & Yes & Yes & Yes \\
\hline Year FE & Yes & Yes & Yes & Yes \\
\hline Observations & 3,351 & 3,351 & 2,742 & 2,742 \\
\hline Adjusted $R^{2}$ & 0.29 & 0.30 & 0.30 & 0.30 \\
\hline
\end{tabular}

The top (bottom) panel of the table reports the first-stage (reduced-form) results of the 2SLS estimates in Table 4. In columns

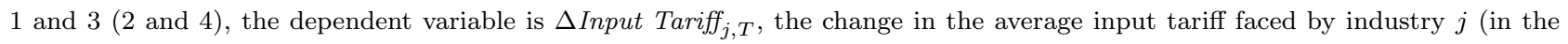
tariff on the key input of industry $j$ ). during term $T$. In columns $5-8$, the dependent variable is $\Delta L_{j, T}$, the annualized log change in employment in SIC4 industry $j$ during term $T$. The sample covers 1988-2016. In columns 1, 2, 5, and 6 (3, 4, 7, and 8), it comprises all sectors (only manufacturing sectors). Observations are weighted by 1988 employment. Standard errors are clustered at the SIC3 industry level; ***, **, and * denote significance at the $1 \%, 5 \%$, and $10 \%$ levels respectively. 


\section{Table A-9}

Tariffs and employment in downstream industries (OLS)

\begin{tabular}{lcccc}
\hline \hline & \multicolumn{2}{c}{ All sectors } & \multicolumn{2}{c}{ Manufacturing sectors only } \\
& Average input tariff & Tariff on key input & Average input tariff & Tariff on key input \\
& $(1)$ & $(2)$ & $(3)$ & $(4)$ \\
\hline$\Delta$ Input Tariff j,T & $-0.077^{* *}$ & -0.001 & -0.007 & -0.001 \\
& $(0.034)$ & $(0.002)$ & $(0.015)$ & $(0.003)$ \\
SIC4 FE & Yes & Yes & Yes & Yes \\
Year FE & Yes & Yes & Yes & Yes \\
Observations & 3,351 & 3,351 & 2,742 & 2,742 \\
Adjusted $R^{2}$ & 0.50 & 0.50 & 0.42 & 0.42 \\
\hline \hline
\end{tabular}

The table reports OLS estimates. The dependent variable $\Delta L_{j, T}$ is the annualized log change in employment in SIC4 industry $j$ during term T. $\Delta$ Input $_{\text {Tariff }}^{j, T}$ is the change in the average input tariff of industry $j$ (in columns 1 and 3 ) or in the tariff on the key input of industry $j$ (in columns 2 and 4 ) during term $T$. The sample covers 1988-2016. In columns 1 and 2 (3 and 4 ), it comprises all sectors (only manufacturing sectors). Observations are weighted by 1988 employment. Standard errors are clustered at the SIC3 industry level; ***,**, and $*$ denote significance at the $1 \%, 5 \%$, and $10 \%$ levels respectively.

\section{Table A-10}

Top-10 affected sectors, by number of jobs lost due to input protection

\begin{tabular}{|c|c|c|c|c|}
\hline SIC4 & SIC4 description & $\begin{array}{l}\text { Share of total } \\
\text { US employment }\end{array}$ & Average input tariff & $\begin{array}{c}\text { Employment loss due to } \\
\text { average input tariffs }\end{array}$ \\
\hline 5812 & Eating and drinking places & $7.94 \%$ & $13.4 \%$ & $-213,795$ \\
\hline 1510 & Construction & $5.47 \%$ & $10.2 \%$ & $-167,094$ \\
\hline 5210 & Retail trade & $13.25 \%$ & $3.2 \%$ & $-149,527$ \\
\hline 5012 & Wholesale trade & $6.11 \%$ & $4.1 \%$ & $-88,037$ \\
\hline 8060 & Hospitals & $4.90 \%$ & $6.1 \%$ & $-64,784$ \\
\hline 7532 & Auto repair & $0.67 \%$ & $20.2 \%$ & $-44,648$ \\
\hline 8320 & Social services & $1.14 \%$ & $6.7 \%$ & $-34,557$ \\
\hline 2752 & Commercial printing, lithographic & $0.49 \%$ & $21.9 \%$ & $-30,695$ \\
\hline 7371 & Computer services & $1.60 \%$ & $3.4 \%$ & $-26,903$ \\
\hline 4210 & Trucking & $1.71 \%$ & $4.6 \%$ & $-26,547$ \\
\hline
\end{tabular}

The table lists the ten SIC4 sectors that suffered the largest predicted job losses due to input protection during 1988-2016. Columns 1 and 2 list the SIC codes of these sectors and the corresponding description. Column 3 reports the sector's average share in total US employment, and column 4 indicates the average input tariff faced by the sector. Column 5 reports the predicted number of job losses, derived by using the estimates of our baseline specification (column 1 of Table 4) in equation (11). 


\section{Table A-11}

The impact of tariffs on employment in downstream industries (heterogeneous effects by import dependence)

\begin{tabular}{|c|c|c|}
\hline & $\begin{array}{c}\text { Mean } \\
(1)\end{array}$ & $\begin{array}{c}\text { Median } \\
(2)\end{array}$ \\
\hline \multirow[t]{2}{*}{$\Delta$ Input Tariff $_{j, T}$} & $-0.239 * * *$ & -0.120 \\
\hline & $(0.077)$ & $(0.092)$ \\
\hline \multirow{2}{*}{$\Delta$ Input Tariff $_{j, T} \times$ High Import Dependence $_{j}$} & $-0.404^{*}$ & $-0.350 * *$ \\
\hline & $(0.230)$ & $(0.151)$ \\
\hline SIC4 FE & Yes & Yes \\
\hline Term FE & Yes & Yes \\
\hline Observations & 3,351 & 3,351 \\
\hline KP F-statistic & 91.5 & 55.5 \\
\hline F-statistic for the sum & $7.98^{* * *}$ & $12.72^{* * *}$ \\
\hline
\end{tabular}

The table reports 2SLS estimates. The dependent variable $\Delta L_{j, T}$ is the annualized log change in employment in SIC4 industry $j$ during term T. $\Delta$ Input Tariff $_{j, T}$ is the change in the average input tariff of industry $j$ during term $T$. In column 1 (column 2 ) the variable High Import Dependence ${ }_{j}$ is a dummy variable equal to 1 if Import Dependence ${ }_{j}$ is higher than the mean (median) level.

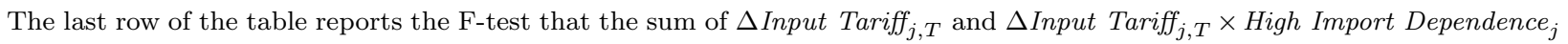
is different from zero. Observations are weighted by 1988 employment. The sample covers all industries for 1988-2016. Standard errors are clustered at the SIC3 industry level; ${ }^{* *},{ }^{* *}$, and $*$ denote significance at the $1 \%, 5 \%$, and $10 \%$ levels respectively.

Table A-12

The impact of tariffs on employment in downstream industries (alternative AD measures)

\begin{tabular}{|c|c|c|c|c|}
\hline & $\begin{array}{l}\text { Product coverage } \\
\text { (1) }\end{array}$ & $\begin{array}{l}\text { Import coverage } \\
\qquad(2)\end{array}$ & $\begin{array}{l}\text { All TTBs } \\
\quad(3)\end{array}$ & $\begin{array}{c}\text { All countries } \\
(4)\end{array}$ \\
\hline$\Delta$ Input $_{\text {Tariff }}, T$ & $\begin{array}{c}-4.235^{* * *} \\
(1.205)\end{array}$ & $\begin{array}{c}-2.896^{* * *} \\
(0.565)\end{array}$ & $\begin{array}{c}-0.379 * * * \\
(0.101)\end{array}$ & $\begin{array}{c}-0.696^{* * *} \\
(0.213)\end{array}$ \\
\hline SIC4 FE & Yes & Yes & Yes & Yes \\
\hline Year FE & Yes & Yes & Yes & Yes \\
\hline Observations & 3,351 & 3,351 & 3,351 & 3,351 \\
\hline KP F-statistic & 140.4 & $2,669.6$ & 230.8 & 65.1 \\
\hline
\end{tabular}

The table reports 2SLS estimates. The dependent variable $\Delta L_{j, T}$ is the annualized log change in employment in SIC4 industry $j$ during term T. $\Delta$ Input Tariff $_{j, T}$ is the change in the average input tariff of industry $j$ during term $T$. In columns 1 and 2 , the variable $\Delta$ Input Tariff $_{j, T}$ using these alternative measures of AD protection: Product Coverage ${ }_{i, T}$ and Import Coverage ${ }_{i, T}$. In column 3, the variable is constructed using information on all US TTBs (AD duties, countervailing duties, and safeguards) against China, while in column 4 it is based on all US AD duties (against all targeted countries). Observations are weighted by 1988 employment. The sample covers all industries for 1988-2016. Standard errors are clustered at the SIC3 industry level; $* * *, * *$, and $*$ denote significance at the $1 \%, 5 \%$, and $10 \%$ levels respectively. 
Table A-13

The impact of tariffs on employment in downstream industries (additional tariffs)

\begin{tabular}{|c|c|c|c|}
\hline & $\begin{array}{c}\text { AD duties } \\
(1)\end{array}$ & $\begin{array}{c}\text { US MFN tariffs } \\
(2)\end{array}$ & Chinese AD duties \\
\hline$\Delta$ Input Tariff ${ }_{j, T}$ & $\begin{array}{c}-0.144^{* *} \\
(0.057)\end{array}$ & $\begin{array}{c}-0.305^{* * *} \\
(0.081)\end{array}$ & $\begin{array}{c}-0.306^{* * *} \\
(0.084)\end{array}$ \\
\hline$\Delta$ Tariff $_{j, T}$ & $\begin{array}{l}-0.032 \\
(0.030)\end{array}$ & & \\
\hline$\Delta$ Input Tariff $M F N_{j, T}$ & & $\begin{array}{l}-0.353 \\
(0.245)\end{array}$ & \\
\hline$\Delta$ Input Retaliation $_{j, T}$ & & & $\begin{array}{c}-0.109 * * \\
(0.047)\end{array}$ \\
\hline$\Delta$ Retaliation $_{j, T}$ & & & $\begin{array}{l}-0.007 \\
(0.014)\end{array}$ \\
\hline SIC4 FE & Yes & Yes & Yes \\
\hline Year FE & Yes & Yes & Yes \\
\hline Observations & 2,833 & 3,351 & 3,351 \\
\hline KP F-statistic & 7.97 & 212.7 & 231.6 \\
\hline
\end{tabular}

The table reports 2SLS estimates. The dependent variable $\Delta L_{j, T}$ is the annualized log change in employment in SIC4 industry $j$ during term T. $\Delta$ Input Tariff $_{j, T}$ is the change in the average input tariff of industry $j$ during term T. $\Delta$ Tariff $_{j, T}$ is the change in the the average AD duty in SIC4 industry $j$ during term T. $\triangle$ Input Tariff $M F N_{j, T}$ is the change in the average US MFN tariff applied on inputs of industry $j . \Delta$ Input Retaliation $_{j, T}$ is the change in the average AD duty applied by China on inputs of industry $j . \Delta$ Retaliation $_{j, T}$ is the change in the AD duty applied by China on industry $j$. Observations are weighted by 1988 employment. The sample covers all industries for 1988-2016. Standard errors are clustered at the SIC3 industry level; $* * *, * *$, and $*$ denote significance at the $1 \%, 5 \%$, and $10 \%$ levels respectively.

\section{Table A-14}

The impact of tariffs on employment in downstream industries (alternative IO linkages)

\begin{tabular}{lcccc}
\hline \hline & \multicolumn{2}{c}{ Total requirements } & \multicolumn{2}{c}{ Diagonal } \\
& Average input & Tariff on key & Average input & Tariff on key \\
& tariff & input & tariff & input \\
& $(1)$ & $(2)$ & $(3)$ & $(4)$ \\
\hline$\Delta$ Input Tariff $j, T$ & $-0.362^{* * *}$ & $-0.025^{*}$ & $-0.327^{* * *}$ & $-0.047^{* * *}$ \\
& $(0.095)$ & $(0.014)$ & $(0.078$ & $(0.005)$ \\
SIC4 FE & Yes & Yes & Yes & Yes \\
Year FE & Yes & Yes & Yes & Yes \\
Observations & 3,351 & 3,351 & 3,351 & 3,351 \\
KP F-statistic & 170.0 & 578.6 & 375.9 & $1,093.3$ \\
\hline \hline
\end{tabular}

The table reports 2SLS estimates. The dependent variable $\Delta L_{j, T}$ is the annualized log change in employment in SIC4 industry

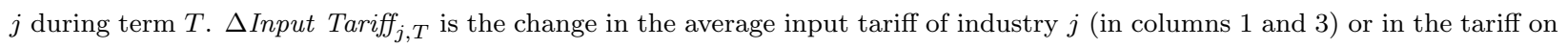
the key input of industry $j$ (in columns 2 and 4) during term $T$. In columns 1 and 2 , we use the total requirement coefficients $\theta_{i, j}$ to construct $\Delta$ Input Tariff $j_{, T}$ (excluding $\theta_{j, j}$ ), while in columns 3 and 4 we use the direct requirement coefficients $\omega_{i, j}$ (including $\omega_{j, j}$ ). Observations are weighted by 1988 employment. The sample covers all industries for 1988-2016. Standard errors are clustered at the SIC3 industry level; ***, **, and * denote significance at the $1 \%, 5 \%$, and $10 \%$ levels respectively. 


\section{Table A-15}

The impact of tariffs on employment in downstream industries

(political importance of industries)

\begin{tabular}{lcccc}
\hline \hline & Alternative Swing $_{i, T}$ & \multicolumn{3}{c}{ Political controls } \\
& $(1)$ & $(2)$ & $(3)$ & $(4)$ \\
\hline$\Delta$ Input Tariff $_{j, T}$ & $-0.311^{* * *}$ & $-0.359^{* * *}$ & $-0.313^{* * *}$ & $-0.368^{* * *}$ \\
& $(0.092)$ & $(0.103)$ & $(0.095)$ & $(0.107)$ \\
$\Delta$ Input Swing $_{j, T}$ & & 0.007 & & 0.008 \\
& & $(0.007)$ & & $(0.006)$ \\
$\Delta$ Swing $_{j, T}$ & & & -0.548 & -0.566 \\
& & & $(0.461)$ & $(0.452)$ \\
SIC4 FE & Yes & Yes & Yes & Yes \\
Year FE & Yes & Yes & Yes & Yes \\
Observations & 3,351 & 3,351 & 3,351 & 3,351 \\
KP F-statistic & 192.7 & 143.9 & 194.5 & 148.6 \\
\hline \hline
\end{tabular}

The table reports 2SLS estimates. The dependent variable $\Delta L_{j, T}$ is the annualized log change in employment in SIC4 industry $j$ during term $T . \Delta$ Input Tariff $_{j, T}$ is the change in the average input tariff of industry $j$ during term $T . \Delta$ Swing $_{j, T}$ captures the change in the political importance of industry $j$, while $\Delta$ Input Swing $_{j, T}$ measures the change in the average political importance of its input industries. All control variables are constructed based on employment in all industries in states classifies as swing in term T. Observations are weighted by 1988 employment. The sample covers all industries for 1988-2016. Standard errors are clustered at the SIC3 industry level; ${ }^{* * *},{ }^{* *}$, and ${ }^{*}$ denote significance at the $1 \%, 5 \%$, and $10 \%$ levels respectively.

Table A-16

The impact of tariffs on downstream industries (alternative econometric methodologies)

\begin{tabular}{|c|c|c|c|c|}
\hline & $\begin{array}{c}\text { Level } \\
\text { regressions } \\
(1)\end{array}$ & $\begin{array}{c}\text { Year } \\
\text { differences } \\
(2)\end{array}$ & $\begin{array}{l}\text { Unweighted } \\
\text { regressions } \\
(3)\end{array}$ & $\begin{array}{c}\text { SIC2 } \\
\text { clusters } \\
(4)\end{array}$ \\
\hline Input $_{\text {Tariff }}^{j, T}$ & $\begin{array}{c}-1.154^{* * *} \\
(0.413)\end{array}$ & & & \\
\hline$\Delta$ Input $_{\text {Tariff }}, T$ & & $\begin{array}{c}-1.235^{* * *} \\
(0.341)\end{array}$ & $\begin{array}{c}-0.152^{* * *} \\
(0.046)\end{array}$ & $\begin{array}{c}-0.319^{* * *} \\
(0.104)\end{array}$ \\
\hline SIC4 FE & Yes & Yes & Yes & Yes \\
\hline Year FE & Yes & Yes & Yes & Yes \\
\hline Observations & 3,351 & 13,407 & 3,351 & 3,351 \\
\hline KP F-statistic & 142.4 & 229.0 & 156.7 & 168.7 \\
\hline
\end{tabular}

The table reports 2 SLS estimates. In columns 1, the dependent variable is the level of employment in SIC4 industry $j$ at the end of term $T$; in column 2, it is the log change in employment in SIC4 industry $j$ between years $t$ and $t-1$; in column 3 and 4 , it is the annualized log change in employment in SIC4 industry $j$ during term T. Input Tariff $j_{j, T}$ is the average input tariff of industry $j$, while $\Delta$ Input Tariff $_{j, T}$ is the change in the average input tariff of industry $j$. Observations are weighted by 1988 employment (in columns 1, 2 and 4) and not weighted (column 3). The sample covers all industries for 1988-2016. Standard errors are clustered at the SIC3 level in columns 1-2, and SIC2 level in columns 3-4. ***, **, and * denote significance at the $1 \%, 5 \%$, and $10 \%$ levels respectively. 


\section{Table A-17}

The effects of tariffs in the protected industries

\begin{tabular}{lcccccc}
\hline \hline & Employment & $\begin{array}{c}\text { Blue } \\
\text { Collar }\end{array}$ & $\begin{array}{c}\text { White } \\
\text { Collar }\end{array}$ & Wages & Sales & Investment \\
& $(1)$ & $(2)$ & $(3)$ & $(4)$ & $(5)$ & $(6)$ \\
\hline \hline$\Delta$ Tariff $j, T^{*}$ & -0.024 & -0.024 & -0.014 & 0.006 & -0.018 & $0.110^{* * *}$ \\
& $(0.025)$ & $(0.031)$ & $(0.016)$ & $(0.007)$ & $(0.066)$ & $(0.034)$ \\
SIC4 FE & Yes & Yes & Yes & Yes & Yes & Yes \\
Term FE & Yes & Yes & Yes & Yes & Yes & Yes \\
Observations & 2,833 & 2,320 & 2,320 & 2,320 & 2,320 & 2,320 \\
KP F-statistic & 16.3 & 10.5 & 10.5 & 10.5 & 10.5 & 10.5 \\
\hline \hline
\end{tabular}

The table reports 2 SLS estimates. The dependent variable is the annualized log change in employment (column 1), the number of blue-collar jobs (column 2), white-collar jobs (column 3), wages (column 4), sales (column 5), and investment (column 6) in SIC4 industry $j$ during term $T . \Delta$ Tariff $_{j, T}$ is the change in the the average AD duty in SIC4 industry $j$ during term $T$. In column 1, and the sample covers all tradable industries in 1991-2016; in columns 2-6, the sample covers all manufacturing industries in 1991-2011. Observations are weighted by 1988 employment. Standard errors are clustered at the SIC3 industry level; $* * * * *$, and $*$ denote significance at the $1 \%, 5 \%$, and $10 \%$ levels respectively. 
CENTRE FOR ECONOMIC PERFORMANCE

Recent Discussion Papers

\begin{tabular}{|c|c|c|}
\hline 1738 & $\begin{array}{l}\text { Christian Krekel } \\
\text { Julia Rechlitz } \\
\text { Johannes Rode } \\
\text { Alexander Zerrahn }\end{array}$ & $\begin{array}{l}\text { Quantifying the externalities of renewable } \\
\text { energy plants using wellbeing data: The case } \\
\text { of biogas }\end{array}$ \\
\hline 1737 & $\begin{array}{l}\text { Nick Jacob } \\
\text { Giordano Mion }\end{array}$ & The UK's great demand and supply recession \\
\hline 1736 & $\begin{array}{l}\text { Gabriel M. Ahlfeldt } \\
\text { Fabian Bald } \\
\text { Duncan Roth } \\
\text { Tobias Seidel }\end{array}$ & Quality of life in a dynamic spatial model \\
\hline 1735 & Kilian Huber & $\begin{array}{l}\text { Are bigger banks better? Firm-level evidence } \\
\text { from Germany }\end{array}$ \\
\hline 1734 & $\begin{array}{l}\text { César Ducruet } \\
\text { Réka Juhász } \\
\text { Dávid Krisztián Nagy } \\
\text { Claudia Steinwender }\end{array}$ & All aboard: the effects of port development \\
\hline 1733 & $\begin{array}{l}\text { Jonathan Colmer } \\
\text { John Voorheis }\end{array}$ & $\begin{array}{l}\text { The grandkids aren't alright: the } \\
\text { intergenerational effects of prenatal pollution } \\
\text { exposure }\end{array}$ \\
\hline 1732 & $\begin{array}{l}\text { Kabir Dasgupta } \\
\text { André Diegmann } \\
\text { Tom Kirchmaier } \\
\text { Alexander Plum }\end{array}$ & $\begin{array}{l}\text { Heterogeneity in criminal behavior after child } \\
\text { birth: the role of ethnicity }\end{array}$ \\
\hline 1731 & $\begin{array}{l}\text { Andreas Diemer } \\
\text { Tanner Regan }\end{array}$ & $\begin{array}{l}\text { No inventor is an island: social connectedness } \\
\text { and the geography of knowledge flows in the } \\
\text { US }\end{array}$ \\
\hline 1730 & $\begin{array}{l}\text { Hanming Fang } \\
\text { Chunmian Ge } \\
\text { Hanwei Huang } \\
\text { Hongbin Li }\end{array}$ & $\begin{array}{l}\text { Pandemics, global supply chains, and local } \\
\text { labor demand: evidence from } 100 \text { million } \\
\text { posted jobs in China }\end{array}$ \\
\hline
\end{tabular}




\begin{tabular}{|c|c|c|}
\hline 1729 & $\begin{array}{l}\text { Ria Ivandić } \\
\text { Tom Kirchmaier } \\
\text { Ben Linton }\end{array}$ & $\begin{array}{l}\text { Changing patterns of domestic abuse during } \\
\text { COVID-19 lockdown }\end{array}$ \\
\hline 1728 & $\begin{array}{l}\text { Jonathan Colmer } \\
\text { Ralf Martin } \\
\text { Mirabelle Muûls } \\
\text { Ulrich J. Wagner }\end{array}$ & $\begin{array}{l}\text { Does pricing carbon mitigate climate change? } \\
\text { Firm-level evidence from the European Union } \\
\text { emissions trading scheme }\end{array}$ \\
\hline 1727 & $\begin{array}{l}\text { Tony Beatton } \\
\text { Michael P. Kidd } \\
\text { Matteo Sandi }\end{array}$ & School indiscipline and crime \\
\hline 1726 & $\begin{array}{l}\text { Maximilian v. Ehrlich } \\
\text { Henry G. Overman }\end{array}$ & $\begin{array}{l}\text { Place-based policies and spatial disparities } \\
\text { across European cities }\end{array}$ \\
\hline 1725 & $\begin{array}{l}\text { Gabriel M. Ahlfeldt } \\
\text { Thilo N. H. Albers } \\
\text { Kristian Behrens }\end{array}$ & Prime Locations \\
\hline 1724 & $\begin{array}{l}\text { Benjamin Handel } \\
\text { Jonathan Kolstad } \\
\text { Thomas Minten } \\
\text { Johannes Spinnewijn }\end{array}$ & $\begin{array}{l}\text { The Social Determinants of Choice Quality: } \\
\text { Evidence from Health Insurance in the } \\
\text { Netherlands }\end{array}$ \\
\hline 1723 & $\begin{array}{l}\text { Claudia Hupkau } \\
\text { Barbara Petrongolo }\end{array}$ & $\begin{array}{l}\text { Work, Care and Gender During the Covid-19 } \\
\text { Crisis }\end{array}$ \\
\hline 1722 & $\begin{array}{l}\text { Ross Levine } \\
\text { Yona Rubinstein }\end{array}$ & $\begin{array}{l}\text { Selection Into Entrepreneurship and Self- } \\
\text { Employment }\end{array}$ \\
\hline 1721 & Sandra McNally & $\begin{array}{l}\text { Gender Differences in Tertiary Education: } \\
\text { What Explains STEM Participation? }\end{array}$ \\
\hline 1720 & $\begin{array}{l}\text { Edoardo di Porto } \\
\text { Paolo Naticchioni } \\
\text { Vincenzo Scrutinio }\end{array}$ & $\begin{array}{l}\text { Partial Lockdown and the Spread of Covid- } \\
\text { 19: Lessons From the Italian Case }\end{array}$ \\
\hline
\end{tabular}

The Centre for Economic Performance Publications Unit

Tel: +44 (0)2079557673 Email info@cep.lse.ac.uk

Website: http://cep.lse.ac.uk Twitter: @CEP_LSE 